\title{
16. PLEISTOCENE AND OLIGOCENE-MIOCENE CALCAREOUS NANNOFOSSILS FROM THE SUMISU RIFT AND IZU-BONIN FOREARC BASIN ${ }^{1}$
}

\author{
John V. Firth ${ }^{2}$ and MaLynn Isiminger-Kelso ${ }^{3}$
}

\begin{abstract}
During Ocean Drilling Program Leg 126, we recovered three expanded Pleistocene sections from the active backarc rift (Sumisu Rift) and three expanded Oligocene-Miocene sections from the forearc basin of the Izu-Bonin volcanic island arc. Quantitative analysis of the Pleistocene nannofossils revealed five major assemblages between 0 and 1.0 Ma: Assemblage 1 (Holocene-0.085 Ma) contains dominant Emiliania huxleyi; Assemblage 2 (ca. 0.085-0.275 Ma) contains dominant small Gephyrocapsa and common E. huxleyi and Gephyrocapsa oceanica; Assemblage 3 (ca. 0.275-0.6 Ma) contains dominant Gephyrocapsa caribbeanica; Assemblage 4 (ca. 0.6-0.9 Ma) contains a peak abundance of small Gephyrocapsa in the middle part, and dominant occurrences of two types of G. caribbeanica in the lower and upper parts; and Assemblage 5 (ca. 0.9-1.0 Ma) contains dominant small Gephyrocapsa and common G. caribbeanica and Reticulofenestra asanoi. These assemblages are largely synchronous with similar assemblages recognized from tropical and subtropical regions, and can be used for finer subdivision of the Pleistocene than that based on standard Pleistocene nannofossil datums.

The Oligocene-Miocene sections contain several hiatuses: up to 3 m.y. may be missing from the uppermost Oligocene (Zone CP19) at Sites 792 and 793; all of Zone CN2 is missing at Sites 792 and 793; part of Zone CN3 and all of Zone CN4 are missing at Site 792. Biochronology of several nannofossil datums at Leg 126 sites indicate that Sphenolithus distentus, Sphenolithus ciperoensis, Cyclicargolithus floridanus, and Discoaster kugleri have diachronous occurrences compared with other sites in the western Pacific Ocean and Philippine Sea.
\end{abstract}

\section{INTRODUCTION}

During Leg 126 of the Ocean Drilling Program (ODP), we drilled the active backarc rift (Sumisu Rift) and the forearc basin of the Izu-Bonin intraoceanic island arc (Fig. 1) to investigate the origin and evolution of backarc and forearc rifting, and the nature of volcanic rocks in the backarc and forearc basins. Drilling in these two regions recovered two different sedimentary histories (Taylor, Fujioka, et al., 1990). The Sumisu Rift yielded two expanded Pleistocene sections (Site $790-270 \mathrm{~m}$ and Site $791-830 \mathrm{~m}$ ) of $1.1 \mathrm{Ma}$ or younger. The sediments at these two sites are primarily thick pumiceous gravel and vitric sand deposits overlying a sequence of nannofossil rich silty clays that, in turn, overlie basaltic rocks. Site 792 in the forearc basin also has an expanded $(100 \mathrm{~m})$ Pleistocene sequence of $\leq 1.1 \mathrm{Ma}$ that unconformably overlies upper Pliocene sediments. This Pleistocene section is composed of vitric sands and pumiceous gravels interbedded with nannofossil-rich silty clays.

Pleistocene sediments greater than 1.1 Ma were not recovered at any sites during Leg 126 . The forearc basin yielded three expanded Oligocene-Miocene sections (Site 787-280 m, Site 792-600 m, and Site $793-764 \mathrm{~m}$ ). The Miocene sediments are primarily siltstones and claystones with nannofossil-rich intervals, whereas the Oligocene sediments are primarily composed of coarser volcanic sandstones and conglomerates that overlie andesitic basement rocks. Pliocene sediments were recovered in smaller quantities, relative to other age sediments, at Sites 787, 788, and 792. The basic biostratigraphy of the Pliocene sediments was completed aboard the JOIDES Resolution and is described in Taylor, Fujioka, et al. (1990). We concentrate in this paper on the calcareous nannofossil assemblages recovered in the expanded Pleistocene, Miocene, and Oligocene sections of the Izu-Bonin active backarc rift and forearc basins, and their importance for local and regional correlation of sedimentary sequences in the Western Pacific. The Pleistocene assemblages were

\footnotetext{
'Taylor, B., Fujioka, K., et al., 1992. Proc. ODP, Sci. Results, 126: College Station, TX (Ocean Drilling Program).

${ }^{2}$ Ocean Drilling Program, 1000 Discovery Drive, Texas A\&M University, College Station, TX 77845-9547, U.S.A.

${ }^{3}$ Department of Geology, Florida State University, Tallahassee, FL 32306, U.S.A.
}

analyzed quantitatively, whereas the Oligocene-Miocene assemblages were analyzed qualitatively.

\section{METHODS}

Smear slides were made from each sample studied. The scanning electron microscope (SEM) was used solely to confirm the presence or absence of Emiliania huxleyi and small Gephyrocapsa in Pleistocene samples. Counts of approximately 300 specimens per sample were made by light microscope in straight transects across smear slides for all Pleistocene samples. The counts did not include Florisphaera profunda, which is dominant in most samples. In addition, these samples were scanned for the presence of marker species. The Pleistocene section at Site 790 is a composite of Holes 790A, 790B, 790C, whereas the section at Site 791 is a composite of Holes 791A and 791B. The holes were correlated based on detailed lithostratigraphy and coring depths (Shipboard Scientific Party, 1990). Age determinations of Pleistocene samples were calculated by interpolations between several biostratigraphic and magnetostratigraphic datums taken from Taylor, Fujioka, et al. (1990), which are listed in Table 1. Each slide from the Oligocene and Miocene samples was scanned at $800 \times$ and $1250 \times$ magnification, and the relative abundances of all species encountered in approximately 300 fields of view were recorded.

\section{TAXONOMIC CLASSIFICATION}

The Pleistocene assemblages, exclusive of Florisphaera profunda, are dominated primarily by specimens of the genus Gephyrocapsa. Numerous attempts have been made to subdivide this genus based on overall size, hole size, crossbar angles, and combinations of these parameters (e.g., Gartner, 1977; Samtleben, 1980; Rio, 1982). In this study, we adopted three broad taxonomic categories that can be recognized under the light microscope: Gephyrocapsa spp. (small), Gephyrocapsa caribbeanica, and Gephyrocapsa oceanica.

Gephyrocapsa spp. (small) encompasses specimens smaller than $3 \mu \mathrm{m}$ in size (e.g., Plate 1, Figs. 9-12; Plate 2, Fig. 2). This group may include the species $G$. aperta, $G$. sinuosa, $G$. protohuxleyi, and $G$. ornata, among others. Very small $G$. caribbeanica (ca. $3 \mu \mathrm{m}$ in size) were distinguished from Gephyrocapsa spp. (small) by having a 


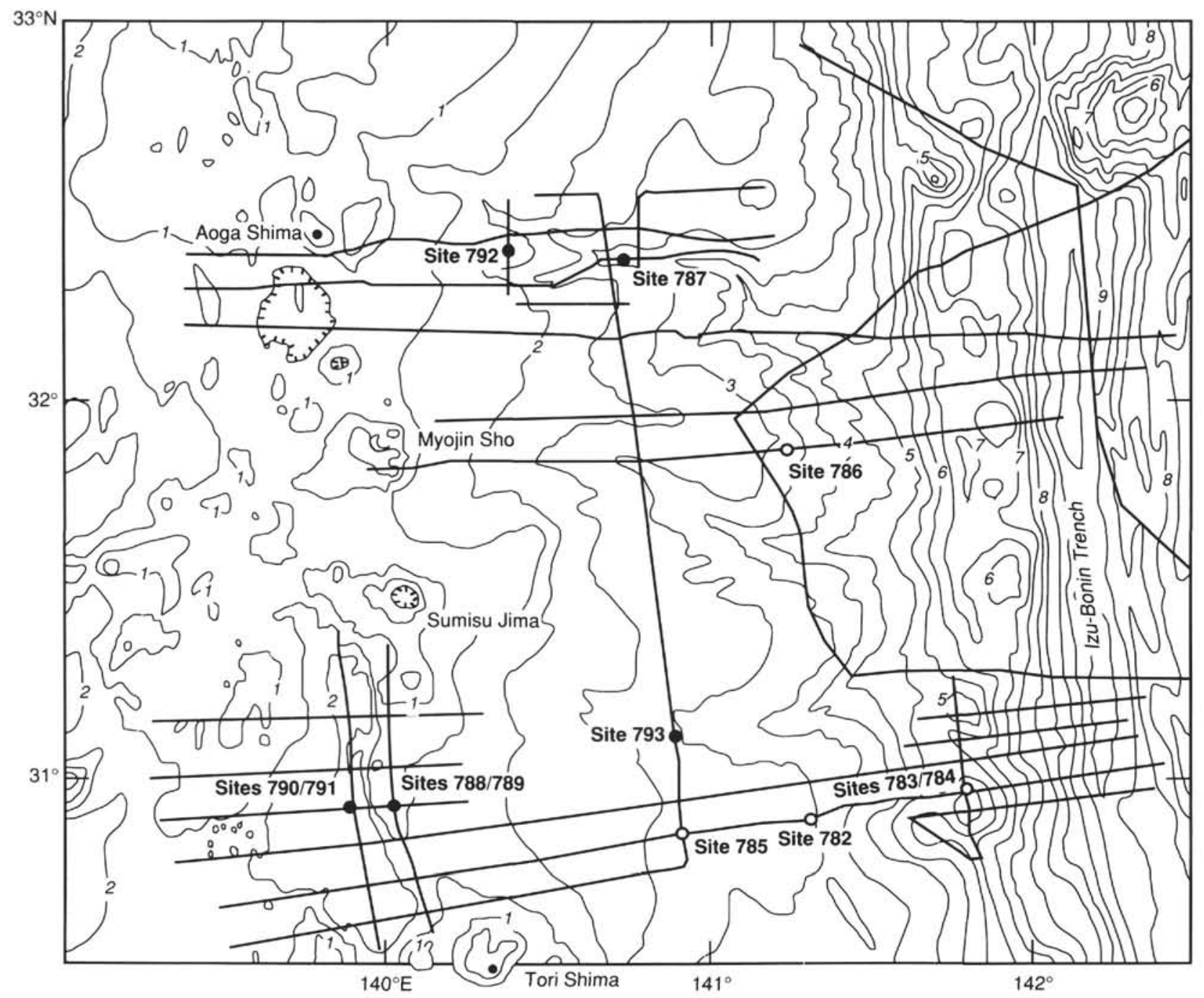

Figure 1. Bathymetric map (in kilometers, with 500-m contour interval) of the Izu-Bonin arc-trench system between $30.5^{\circ}$ and $33^{\circ} \mathrm{N}$. The locations of sites drilled on ODP Legs 125 (open circles) and 126 (solid circles) are shown on the map, as are the locations of site survey multichannel seismic (MCS) lines.

Table 1. Biostratigraphic and magnetostratigraphic datums at Site 790, 791, and 792.

\begin{tabular}{|c|c|c|c|c|}
\hline Datum & $\begin{array}{l}\mathrm{Agc} \\
\text { (Ma) }\end{array}$ & $\begin{array}{c}\text { Sitc } 790 \\
\text { Depth (mbs) }\end{array}$ & $\begin{array}{c}\text { Sitc } 791 \\
\text { Depth (mbsf) }\end{array}$ & $\begin{array}{c}\text { Site } 792 \\
\text { Depth (mbsf) }\end{array}$ \\
\hline $\begin{array}{r}\text { OA Emiliania huxleyi } \\
\text { (nannofossil) }\end{array}$ & 0.085 & $130.6-136.2$ & $275.0-284.7$ & $6.2-9.7$ \\
\hline $\begin{array}{l}\text { FO Emiliania huxleyi } \\
\text { (nannofossil) }\end{array}$ & 0.275 & $181.6-185.3$ & $483.1-504.9$ & $27.0-28.4$ \\
\hline $\begin{array}{c}\text { LO Druppatractus acquilonius } \\
\text { (radiolarian) }\end{array}$ & 0.30 & $181.6-193.9$ & $531.7-540.9$ & - \\
\hline $\begin{array}{c}\text { LO Axoprunum angelinum } \\
\text { (radiolarian) }\end{array}$ & 0.41 & 207.3-213.6 & $604.1-618.1$ & - \\
\hline $\begin{array}{c}\text { LO Pseudoemiliania lacunosa } \\
\text { (nannofossil) }\end{array}$ & 0.46 & $213.6-223.2$ & $652.5-666.0$ & $31.8-37.8$ \\
\hline $\begin{array}{l}\text { Brunhes/Matuyama } \\
\text { (paleomagnetics) }\end{array}$ & 0.73 & $241.7-245.3$ & $747.8-752.2$ & $58.0-59.9$ \\
\hline $\begin{array}{l}\text { LO Reticulofenestra asanoi } \\
\text { (nannofossil) }\end{array}$ & 0.83 & $248.5-253.3$ & $775.8-781.3$ & $69.5-76.2$ \\
\hline $\begin{array}{l}\text { Jaramillo Top } \\
\text { (palcomagnetics) }\end{array}$ & 0.91 & $256.2-257.4$ & $792.6-807.5$ & $80.0-85.2$ \\
\hline $\begin{array}{l}\text { Jaramillo Bottom } \\
\text { (paleomagnetics) }\end{array}$ & 0.98 & $260.0-265.9$ & $820.8-827.6$ & $86.8-91.1$ \\
\hline
\end{tabular}

Note: Age values of samples studied were calculated by interpolation between these datums. 
noticeable shield around the central rim that surrounds the central hole. Small Gephyrocapsa spp. primarily show only a single bright rim around the central hole, without a noticeable shield extending out from it.

Our definitions for $G$. caribbeanica and $G$. oceanica compare closely, though not exactly, with the definitions by Matsuoka and Okada (1989) of $G$. caribbeanica and $G$. oceanica, respectively. We chose a minimum size cutoff of $3 \mu \mathrm{m}$ for these species because that size was easier to determine than the $2.5-\mu \mathrm{m}$ cutoff determined with an SEM by Matsuoka and Okada (1989). Gephyrocapsa caribbeanica (Plate 1, Figs. 3-4, 7-8) encompasses specimens with small central holes (generally less than one-third the width of the overall placolith) and commonly have crossbar angles from $45^{\circ}$ to $90^{\circ}$ (measured from the short axis of the placolith). Specimens of G. caribbeanica are generally smaller than G. oceanica and range from 3 to $5 \mu \mathrm{m}$ in size, although some specimens may be $>5 \mu \mathrm{m}$. Gephyrocapsa oceanica (Plate 1,Figs. 1-2,5-6) encompasses specimens with noticeably open central holes (generally equal to or greater than one-third the width of the overall placolith), and commonly have crossbar angles from $0^{\circ}$ to $45^{\circ}$. Specimens of $G$. oceanica usually range from 4 to $6 \mu \mathrm{m}$, although they may be as small as $3-4 \mu \mathrm{m}$.

These three morphologic categories, Gephyrocapsa spp. (small), $G$. caribbeanica, and $G$. oceanica, are arbitrarily defined, and some morphologic gradations and overlap exist within and between the groups. The definitions used may not follow exactly other definitions of these groups; however, as will be discussed later, the abundance fluctuation patterns of these groups can be compared favorably with other studies on the Gephyrocapsa complex.

Various species of Helicosphaera were observed in the Pleistocene samples, but they were usually rare and sporadic in their occurrences. These were grouped under Helicosphaera spp., except for Helicosphaera inversa, which is reported by Takayama and Sato (1987) to have a stratigraphically useful range from 0.48 to $0.15 \mathrm{Ma}$ in the upper Pleistocene.

Firth (in press), Olafsson (in press), and $\mathrm{Xu}$ and Wise (in press) consider Cyclicargolithus abisectus and Cyclicargolithus floridanus to be just one species that displays variations in size. Therefore, we have included all specimens of Cyclicargolithus under the name $C$. floridanus.

Within the Miocene, the variable Reticulofenestra complex was divided into two species: Reticulofenestra pseudoumbilica sensu lato and Reticulofenestra spp. (small). Small Reticulofenestra spp. encompasses all forms $\varsigma \mu \mathrm{m}$ in size and includes species such as Reticulofenestra minuta, Reticulofenestra minutula, and Reticulofenestra haqii (see Backman, 1980). Specimens $>5 \mu \mathrm{m}$ were included in $R$. pseudoumbilica sensu lato, following the results of Backman (1980). Great variability in relative hole size is observed in this species, encompassing forms also attributable to Reticulofenestra gelida and, rarely, Dictyococcites antarcticus. The overall size of $R$. pseudoumbilica increases through the Miocene to include specimens as large as $13 \mu \mathrm{m}$ in the upper Miocene to Pliocene at Site 792. The genus Reticulofenestra also includes one large species in the Pleistocene, $R$. asanoi (Plate 1, Figs. 15-16; Plate 3, Fig. 1), which is greater than $6 \mu \mathrm{m}$ in size and has a restricted stratigraphic range (Sato and Takayama, in press).

\section{PLEISTOCENE}

\section{Results}

Good core recovery and good magneto- and biostratigraphy through much of the Pleistocene sections allowed us to study nannofossil assemblage changes on a very fine time scale (in many cases $<10,000$-yr sample spacing, and mostly <100,000-yr sample spacing). Comparison with similar detailed Pleistocene studies such as Matsuoka and Okada (1989, 1990) should help to determine the geographic extent and synchroneity of fine-scale nannofossil assemblage changes.

Results of the counts of 300 specimens per sample for Sites 790 and 791 and for Hole 792A are found in Tables 2-4. Four nannofossil datums are recognized in each section: The last occurrence (LO) of Reticulofenestra asanoi ( $0.83 \mathrm{Ma})$, the LO of Pseudoemiliania lacunosa
(0.46 Ma), the first occurrence (FO) of Emiliania huxleyi (0.275 Ma), and the onset of the acme (OA) of $E$. huxleyi. The E. huxleyi acme datum is time-transgressive from $0.085 \mathrm{Ma}$ in tropical and subtropical regions to $0.073 \mathrm{Ma}$ in transitional to high latitudes (Thierstein et al., 1977). The value of $0.073 \mathrm{Ma}$ was also calculated for a subtropical site $\left(21^{\circ} \mathrm{N}\right)$, however, that had apparently been under the influence of transitional water masses (Thierstein et al., 1977). Until direct correlation of this datum with oxygen isotope stages can be made for the Leg 126 sites, we use the value of $0.085 \mathrm{Ma}$ from Thierstein et al. (1977).

Three nannofossil datums of Takayama and Sato (1987) were sought but not found in this study: the FO of Gephyrocapsa parallela, and the FO and LO of Helicosphaera inversa. The FO of Gephyrocapsa parallela was reported as 0.89 Ma by Takayama and Sato (1986). According to the classification of Gephyrocapsa used in this study, this species would be a morphotype of $G$. oceanica with a bridge angle of about $0^{\circ}$. Although many $G$. oceanica show low bridge angles in the lower part of our sections, the $G$. parallela morphotype forms only a small component of the group, and a termination of its range below approximately $0.9 \mathrm{Ma}$ in our samples is not noticeable. The variability of the $G$. parallela datum (0.78-1.05 Ma) reported by Takayama and Sato (1987) suggests that the lower range of this form in the Leg 126 region could be older than our oldest studied Pleistocene samples (about 1.0 Ma).

The FO and LO of Helicosphaera inversa were not biostratigraphically useful in our samples because of the rare and sporadic occurrence of this species. These datums were assigned age values of 0.48 and 0.15 $\mathrm{Ma}$, respectively (Takayama and Sato, 1987). Helicosphaera inversa occurs as old as $0.77 \mathrm{Ma}$ at Site 791 (Table 4), and as young as $1.2 \mathrm{Ka}$ at Site 790 (Table 3 ). The anomalously young occurrence may be attributed to reworking. The older occurrence, however, agrees well with the reported occurrence of $H$. invers $a$ at $0.7 \mathrm{Ma}$ in a piston core from the West Mariana Ridge (Matsuoka and Okada, 1989). Thus, the utility of this species for correlations in the North Atlantic does not seem to extend to the Western Pacific.

Five nannofossil assemblages can be recognized in all three Pleistocene sections (Figs. 2 and 3 ). The assemblages are numbered from 1 to 5 , with Assemblage 1 being the youngest and Assemblage 5 being the oldest.

Assemblage 1 is marked by a dominance of $E$. huxleyi and common $G$. oceanica. Both $G$. caribbeanica and small Gephyrocapsa form only minor components of the assemblage. Assemblage 1 represents the time interval from 0 to $0.085 \mathrm{Ma}$.

Assemblage 2 is marked by the common occurrence of $E$. huxleyi and G. oceanica, and an abundance of small Gephyrocapsa. Gephyrocapsa caribbeanica is generally sparse, but is abundant in the lowest part of this assemblage at Sites 790 and 792 . Assemblage 2 represents the time interval from about 0.085 to $0.275 \mathrm{Ma}$.

Assemblage 3 represents the time interval from about 0.275 to $0.6 \mathrm{Ma}$. It is characterized by a dominance of $G$. caribbeanica $(>60 \%)$. Small Gephyrocapsa comprise $<30 \%$ of the assemblage, except during short peak abundance periods. The most prominent peak abundance of small Gephyrocapsa, which occurred at about 0.4 $\mathrm{Ma}$ at Sites 790 and 791, is not evident at Site 792. Gephyrocapsa oceanica forms a very minor component of this assemblage but it increases in abundance near the top.

Assemblage 4 represents the time interval 0.6 to $0.9 \mathrm{Ma}$. Small Gephyrocapsa and G. caribbeanica make up roughly equal components $(30 \%-50 \%)$ in the lower part of the assemblage (time interval 0.8 to $0.9 \mathrm{Ma}$ ). The middle part of the assemblage is characterized by a peak abundance ( $>90 \%$ ) of small Gephyrocapsa (time interval 0.7 to $0.8 \mathrm{Ma}$ ). This abundance peak declines in the upper part to $<30 \%$ and is replaced by a gradual increase in abundance $(>60 \%)$ of $G$. caribbeanica (time interval 0.6 to $0.7 \mathrm{Ma}$ ). Gephyrocapsa oceanica comprises $<10 \%$ of the assemblage, except at Site 790 where its relative abundance increases to about $15 \%$ at the top of the assemblage.

The top of Assemblage 5 is about $0.9 \mathrm{Ma}$, whereas the base is undefined and is older than the oldest samples studied (about 1.0 Ma). The assemblage is characterized by a high relative abundance $(50 \%-$ 
Table 2. Numerical abundances of nannofossil taxa encountered in counts of 300 specimens per sample, Site 790.

\begin{tabular}{|c|c|c|c|c|c|c|c|c|c|c|c|c|c|c|c|c|c|c|c|c|c|c|}
\hline Sample & 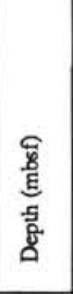 & $\begin{array}{l}\sum_{0}^{\pi} \\
: \\
< \\
<\end{array}$ & 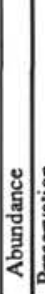 & 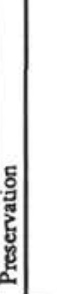 & 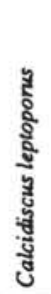 & 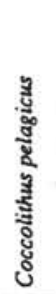 & 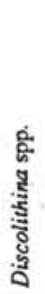 & 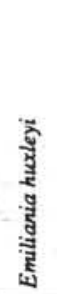 & 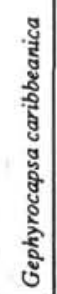 & 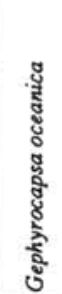 & 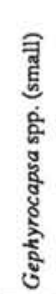 & 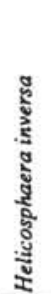 & 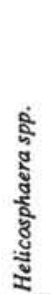 & 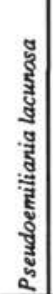 & 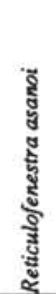 & 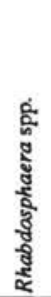 & 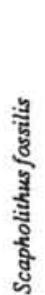 & 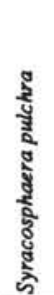 & 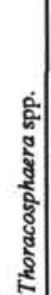 & 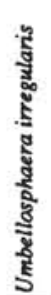 & 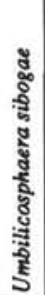 & 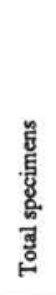 \\
\hline $126-790 \mathrm{~A}-1 \mathrm{H}-1,11-12$ & 0.1 & 0.00006 & A & G] & 8 & 0 & 1 & 231 & 11 & 34 & 0 & 0 & 3 & 0 & 0 & 0 & 0 & 0 & 1 & 1 & 10 & 300 \\
\hline $126-790 \mathrm{~B}-1 \mathrm{H}-1,44-45$ & 0.4 & 0.00025 & A & G & 11 & 0 & 0 & 193 & 33 & 51 & 0 & 0 & 1 & 0 & 0 & 2 & 0 & 1 & of & 0 & 9 & 301 \\
\hline $126-790 \mathrm{~B}-2 \mathrm{H}-3,123-124$ & 8.7 & 0.0055 & A $\mathrm{C}$ & G] & 7 & 0 & 1 & 215 & 5 & 55 & 0 & 0 & 9 & 0 & 0 & 2 & 0 & 0 & 2 & 0 & 4 & 300 \\
\hline $126-790 \mathrm{~A}-2 \mathrm{H}-\mathrm{CC}$ & 18.3 & 0.0012 & c|c & $\mathrm{G}$ & 4 & 0 & 0 & 218 & 48 & 16 & 2 & 1 & 1 & 0 & 0 & 1 & 0 & 2 & o & 3 & 4 & 300 \\
\hline $126-790 \mathrm{~B}-3 \mathrm{H}-6,80-81$ & 22.3 & 0.014 & c|c & G & 11 & 0 & 0 & 214 & 11 & 51 & 1 & 0 & 4 & 0 & 0 & 2 & 0 & 1 & 0 & 1 & 5 & 301 \\
\hline 126-790B-6H-3, 97-98 & 46.5 & 0.030 & c & $\mathrm{G}$ & 8 & 0 & 0 & 235 & 16 & 29 & 2 & 1 & 3 & 0 & 0 & 2 & 0 & 0 & 0 & 3 & 1 & 300 \\
\hline $126-790 \mathrm{~B}-7 \mathrm{H}-\mathrm{CC}$ & 61.6 & 0.039 & $\mathrm{~A}$ & $\mathrm{G}$ & 0 & 1 & 0 & 207 & 17 & 53 & 0 & 0 & 5 & 0 & 0 & 3 & 0 & 1 & 0 & 1 & 4 & 300 \\
\hline $126-790 \mathrm{~B}-8 \mathrm{H}-6,40-41$ & 69.5 & 0.044 & A & $\mathrm{G}$ & 6 & 1 & 0 & 191 & 56 & 31 & 0 & 0 & 5 & 0 & 0 & 3 & 0 & 5 & 0 & 0 & 10 & 300 \\
\hline $126-790 \mathrm{~B}-10 \mathrm{H}-5,40-41$ & 87.4 & 0.056 & c|c & $\mathrm{G}$ & 11 & 0 & 0 & 224 & 23 & 31 & 3 & 0 & 4 & 0 & 0 & 0 & 0 & 1 & 0 & 0 & 4 & 301 \\
\hline $126-790 \mathrm{C}-1 \mathrm{H}-\mathrm{CC}$ & 94.5 & 0.060 & c & G & 9 & 0 & 0 & 143 & 87 & 42 & 18 & 0 & 0 & 0 & 0 & 1 & 0 & 0 & 0 & 0 & 0 & 300 \\
\hline $126-790 \mathrm{~B}-11 \mathrm{H}-6,40-41$ & 98.6 & 0.063 & c|c & G & 9 & 0 & 2 & 173 & 64 & 33 & 5 & 1 & 0 & 0 & 0 & 1 & 0 & 1 & 0 & 3 & 8 & 300 \\
\hline $126-790 \mathrm{C}-3 \mathrm{H}-\mathrm{CC}$ & 113.9 & 0.0725 & c|c & $\mathrm{G}$ & 19 & 0 & 0 & 88 & 104 & 67 & 14 & 0 & 3 & 0 & 0 & 0 & 0 & 0 & 0 & 0 & 5 & 300 \\
\hline $126-790 \mathrm{~B}-15 \mathrm{X}-1,22-24$ & 129.5 & 0.0825 & $\mathrm{~A}$ & G & 9 & 0 & 0 & 184 & 9 & 82 & 8 & 0 & 2 & 0 & 0 & 1 & 0 & 0 & 0 & 0 & 5 & 300 \\
\hline $126-790 \mathrm{C}-5 \mathrm{H}-5,115$ & 130.6 & 0.083 & A : $:$ & $\mathrm{M}$ & 26 & 0 & 0 & 73 & 10 & 172 & 13 & 0 & 2 & 0 & 0 & 0 & 0 & 0 & 1 & 0 & 3 & 300 \\
\hline $126-790 \mathrm{C}-6 \mathrm{H}-3,0$ & 136.2 & 0.096 & A & G & 24 & 0 & 0 & 47 & 16 & 179 & 22 & 0 & 4 & 0 & 0 & 1 & 0 & 1 & 0 & 0 & 6 & 300 \\
\hline $126-790 \mathrm{C}-7 \mathrm{H}-\mathrm{CC}$ & 145.7 & 0.132 & A & G & 8 & 0 & 0 & 47 & 20 & 47 & 169 & 0 & 0 & 0 & 0 & 0 & 1 & 2 & 1 & 2 & 3 & 300 \\
\hline $126-790 C-10 X-1,41-42$ & 165.3 & 0.206 & A & G & 16 & 0 & 0 & 26 & 37 & 28 & 178 & 0 & 6 & 0 & 0 & 2 & 0 & 1 & 0 & 0 & 6 & 300 \\
\hline $126-790 \mathrm{C}-11 \mathrm{X}-1,40-41$ & 175.0 & 0.243 & A & G & 14 & 1 & 0 & 7 & 27 & 123 & 127 & 0 & 0 & 0 & 0 & 0 & 0 & 0 & 0 & 0 & 1 & 300 \\
\hline $126-790 \mathrm{C}-12 \mathrm{X}-1,120-121$ & 185.3 & 0.284 & A & G] & 2 & 0 & 0 & 0 & 200 & 25 & 73 & 0 & 0 & 0 & 0 & 0 & 0 & 0 & 0 & $\mathbf{0}$ & 0 & 300 \\
\hline $126-790 \mathrm{C}-13 \mathrm{X}-1,60$ & 194.5 & 0.331 & A & $\mathrm{G}$ & 6 & 0 & 0 & 0 & 235 & 8 & 49 & 0 & 2 & 0 & 0 & 0 & 0 & 0 & 0 & 0 & 0 & 300 \\
\hline $126-790 \mathrm{C}-14 \mathrm{X}-1,40-41$ & 204.0 & 0.379 & A & G & 1 & 0 & 0 & 0 & 152 & 7 & 137 & 0 & 1 & 0 & 0 & 1 & 0 & 0 & 0 & 0 & 1 & 300 \\
\hline $126-790 \mathrm{C}-14 \mathrm{X}-\mathrm{CC}$ & 213.2 & 0.426 & $\mathrm{~A}$ & G & 3 & 0 & 0 & 0 & 183 & 4 & 107 & 0 & 1 & 0 & 0 & 1 & 0 & 0 & 0 & 0 & 1 & 300 \\
\hline $126-790 \mathrm{C}-16 \mathrm{X}-1,40-41$ & 223.2 & 0.498 & A $\mathrm{C}$ & G & 0 & 0 & 0 & 0 & 277 & 1 & 20 & 0 & 0 & 2 & 0 & 0 & 0 & 0 & 0 & 0 & 0 & 300 \\
\hline $126-790 \mathrm{C}-16 \mathrm{X}-3,40-41$ & 226.2 & 0.534 & $\mathrm{~A}$ & $\mathrm{G}$ & 11 & 0 & 1 & 0 & 235 & 3 & 38 & 0 & 3 & 6 & 0 & 1 & 0 & 0 & 이 & 0 & 2 & 300 \\
\hline $126-790 \mathrm{C}-16 \mathrm{X}-6,20-21$ & 230.5 & 0.585 & $\mathrm{~A}$ & $\mathrm{G}$ & 9 & 0 & 0 & 0 & 97 & 63 & 127 & 0 & 0 & 3 & 0 & 0 & 0 & 0 & 0 & $\mathbf{0}$ & 1 & 300 \\
\hline $126-790 \mathrm{C}-17 \mathrm{X}-1,40-41$ & 232.8 & 0.613 & A $: 1$ & $\mathrm{M}$ & 4 & 1 & 0 & 0 & 209 & 39 & 38 & 0 & 1 & 5 & 0 & 1 & 0 & 0 & 이 & 0 & 2 & 300 \\
\hline $126-790 \mathrm{C}-18 \mathrm{X}-1,40-41$ & 242.5 & 0.728 & $\mathrm{~A}$ & G & 0 & 0 & 0 & 0 & 7 & 3 & 285 & 0 & 0 & 0 & 0 & 1 & 0 & 1 & 0 & 0 & 0 & 297 \\
\hline $126-790 \mathrm{C}-18 \mathrm{X}-5,21-22$ & 248.3 & 0.798 & A & G & 8 & 0 & 2 & 0 & 30 & 15 & 245 & 0 & 0 & 0 & 0 & 0 & 0 & 0 & o & 0 & 0 & 300 \\
\hline $126-790 \mathrm{C}-19 \mathrm{X}-1,40-41$ & 252.1 & 0.844 & $A \mid C$ & $\mathrm{G}$ & 15 & $\mathbf{0}$ & 0 & 0 & 113 & 28 & 132 & 0 & 1 & 1] & 10 & 0 & 0 & 0 & 이 & 0 & 0 & 300 \\
\hline $126-790 \mathrm{C}-19 \mathrm{X}-3,40-41$ & 255.1 & 0.881 & A & G & 6 & 0 & 0 & 0 & 135 & 28 & 126 & 0 & 0 & 1 & 4 & 0 & 0 & 0 & 0 & 0 & 0 & 300 \\
\hline $126-790 C-19 X-5,40-41$ & 258.1 & 0.919 & $\mathrm{~A}$ & G & 4 & 0 & 0 & 0 & 36 & 23 & 221 & $\mathbf{0}$ & 1 & 0 & 15 & 1 & 0 & 0 & 0 & 0 & 0 & 301 \\
\hline $126-790 \mathrm{C}-20 \mathrm{X}-4,8-10$ & 266.0 & 1.018 & A & $\mathrm{G}$ & 1 & 0 & 0 & 0 & 85 & 21 & 187 & 0 & 0 & 0 & 6 & 0 & 0 & 0 & 0 & 0 & 0 & 300 \\
\hline
\end{tabular}

Note: $A$ bundance: $A=a b u n d a n t ~ C=c o m m o n$

Preservation: $\mathrm{G}=$ good, $\mathrm{M}=$ moderate

$80 \%$ ) of small Gephyrocapsa. The relative abundance of $G$. caribbeanica is about $5 \%-15 \%$ near the base and increases up to $50 \%$ (at Site 791) near the top. Gephyrocapsa oceanica and Reticulofenestra asanoi each make up $10 \%$ or less of the assemblage. Calcidiscus leptoporus is few to common, comprising almost $3 \%$ of the assemblage at Site 791 (Fig. 3).

\section{Comparison Between Sites}

The comparison of assemblages between Sites 790 and 791 is of special interest because of their close proximity to each other (about $2 \mathrm{~km}$ ), their comparable water depths ( 2223 and $2268 \mathrm{~m}$, respectively), and their similar lithostratigraphies. It should be reasonable to expect little difference in surface-water or bottom-water paleoenvironmental conditions between the two sites. We might also expect the effects of lithologic variations and diagenetic changes on nannofossil assemblages to be similar in these two sites. If so, any observed differences between the nannofossil assemblages in these two very similar geologic settings will need to be explained by other factors. These factors should, then, also be considered when interpreting differences or similarities in nannofossil assemblages over larger distances and more variable environmental and geologic conditions.

The distribution patterns from Sites 790 and 791 are overall very similar, but have two notable differences. The first is a peak abundance of $G$. oceanica which occurs at Site 790 between 0.55 and $0.65 \mathrm{Ma}$ but does not occur at Site 791. The second is the abundance peaks and minima of small Gephyrocaps $a$ between 0.4 and 0.2 Ma at Site 791, which do not correlate exactly with those at Site 790 . Only the peak abundance at about $0.4 \mathrm{Ma}$ is seen at both sites but the magnitude of the peak is much greater at Site 791 than at Site 790. We postulate several factors that may contribute to these differences: (1) unequal sample spacing, (2) unequal sample preservation, (3) inconsistencies in categorizing the different taxonomic groups or in preparation of the samples, (4) the effect of lithology on smear slide analyses, (5) reworking, or (6) real differences in relative abundances of species over distances of a few kilometers within an open-ocean environment that are preserved in the sediments on the ocean floor. These are addressed in turn below.

The poor recovery at Site 791 below 200 meters below seafloor (mbsf), compared to relatively good core recovery at Site 790 , contributed to uneven sample spacing (Figs. 4 and 5). Short-term fluctuations in nanno- 
Table 3. Numerical abundances of nannofossil taxa encountered in counts of 300 specimens per sample, Site 791.

\begin{tabular}{|c|c|c|c|c|c|c|c|c|c|c|c|c|c|c|c|c|c|c|c|c|c|c|}
\hline Sample & 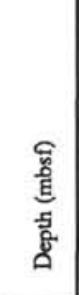 & $\begin{array}{l}\sum_{0}^{\mathrm{d}} \\
\substack{0 \\
<}\end{array}$ & 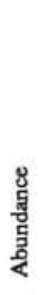 & 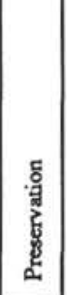 & 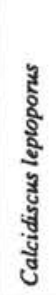 & 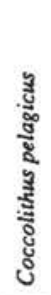 & 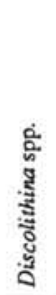 & 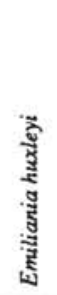 & 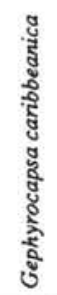 & 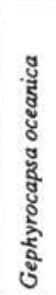 & 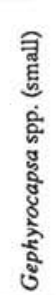 & 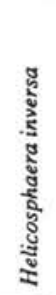 & 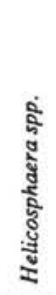 & 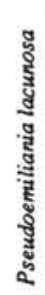 & 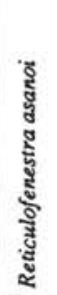 & 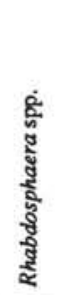 & 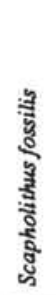 & 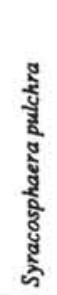 & 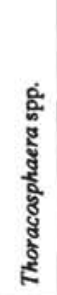 & 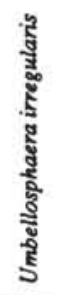 & 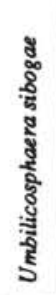 & 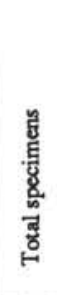 \\
\hline 126-791A-2H-CC & 14.0 & 0.004 & A & G & 14 & 0 & 0 & 178 & 18 & 58 & 10 & 0 & 6 & 0 & 0 & 5 & 1 & 2 & 0 & 2 & 5 & 299 \\
\hline $126-791 \mathrm{~A}-4 \mathrm{H}-\mathrm{CC}$ & 33.0 & 0.010 & A & G & 11 & 0 & 0 & 175 & 18 & 59 & 5 & 0 & 3 & 1 & 0 & 3 & 0 & 6 & 0 & 8 & 7 & 296 \\
\hline $126-791 \mathrm{~A}-6 \mathrm{H}-\mathrm{CC}$ & 52.0 & 0.016 & A & G & 10 & 0 & 1 & 190 & 16 & 53 & 10 & 0 & 6 & 0 & 0 & 0 & 1 & 1 & 0 & 5 & 6 & 298 \\
\hline 126-791A-8H-CC & 71.3 & 0.022 & A & G & 11 & 0 & 0 & 226 & 11 & 42 & 2 & 0 & 4 & 0 & 0 & 1 & 0 & 0 & 0 & 0 & 3 & 300 \\
\hline $126-791 \mathrm{~A}-10 \mathrm{H}-\mathrm{CC}$ & 90.7 & 0.028 & $\mathrm{C}$ & G & 9 & 0 & 3 & 144 & 28 & 77 & 15 & 0 & 7 & 0 & 0 & 3 & 1 & 1 & 0 & 4 & 5 & 297 \\
\hline $126-791 \mathrm{~A}-13 \mathrm{H}-\mathrm{CC}$ & 119.8 & 0.037 & A & G & 10 & 0 & 1 & 204 & 11 & 54 & 3 & 0 & 8 & 0 & 0 & 2 & 0 & 0 & 0 & 1 & 6 & 300 \\
\hline $126-791 \mathrm{~A}-15 \mathrm{H}-\mathrm{CC}$ & 139.2 & 0.043 & A & G & 7 & 0 & 3 & 185 & 11 & 81 & 1 & 0 & 3 & 0 & 0 & 3 & 1 & 0 & 1 & 0 & 4 & 300 \\
\hline $126-791 \mathrm{~A}-17 \mathrm{H}-\mathrm{CC}$ & 158.5 & 0.049 & A & G & 6 & 0 & 1 & 198 & 14 & 62 & 5 & 0 & 4 & 0 & 0 & 3 & 1 & 1 & 1 & 0 & 4 & 300 \\
\hline $126-791 \mathrm{~A}-19 \mathrm{H}-\mathrm{CC}$ & 177.7 & 0.055 & A & G & 15 & 0 & 1 & 144 & 42 & 62 & 19 & 0 & 3 & 1 & 0 & 2 & 0 & 4 & 0 & 1 & 5 & 299 \\
\hline $126-791 \mathrm{~A}-23 \mathrm{H}-\mathrm{CC}$ & 207.9 & 0.064 & A & M-G & 19 & 0 & 0 & 189 & 8 & 65 & 4 & 1 & 3 & 0 & 0 & 2 & 0 & 0 & 0 & 1 & 8 & 300 \\
\hline $126-791 \mathrm{~A}-24 \mathrm{X}-\mathrm{CC}$ & 217.1 & 0.067 & A & G & 18 & 0 & 0 & 194 & 15 & 58 & 2 & 0 & 7 & 1 & 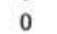 & 0 & 1 & 1 & 0 & 0 & 2 & 299 \\
\hline 126-791A-31X-CC & 284.6 & 0.093 & A & M-G & 11 & 0 & 0 & 143 & 39 & 102 & 2 & 0 & 1 & 0 & 0 & 0 & 0 & 0 & 0 & 0 & 1 & 299 \\
\hline 126-791A-32X-CC & 294.3 & 0.101 & A & $\mathrm{M}$ & 6 & 0 & 0 & 8 & 44 & 47 & 191 & 0 & 2 & 0 & 0 & 2 & 0 & 0 & 0 & 0 & 0 & 300 \\
\hline 126-791A-33X-CC & 304.0 & 0.109 & A & G & 3 & 0 & 0 & 44 & 24 & 55 & 155 & 1 & 3 & 0 & 0 & 1 & 2 & 2 & 0 & 3 & 7 & 300 \\
\hline 126-791A-35X-CC & 323.3 & 0.125 & A & G & 2 & 0 & 0 & 36 & 13 & 106 & 127 & 0 & 1 & 0 & 0 & 3 & 0 & 3 & 0 & 2 & 4 & 296 \\
\hline $126-791 \mathrm{~A}-38 \mathrm{X}-\mathrm{CC}$ & 352.3 & 0.150 & A & G & 23 & 0 & 0 & 28 & 19 & 105 & 113 & 0 & 3 & 1 & 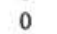 & 1 & 0 & 3 & 0 & 0 & 3 & 299 \\
\hline $126-791 \mathrm{~A}-42 \mathrm{X}-\mathrm{CC}$ & 391.0 & 0.182 & A & G & 17 & 0 & 0 & 29 & 91 & 106 & 52 & 0 & 2 & 0 & 0 & 1 & 0 & 0 & 0 & 0 & 2 & 300 \\
\hline $126-791 \mathrm{~A}-46 \mathrm{X}-\mathrm{CC}$ & 428.4 & 0.213 & C & M & 10 & 1 & 0 & 34 & 110 & 55 & 84 & 0 & 3 & 0 & 0 & 0 & 0 & 0 & 0 & 1 & 2 & 300 \\
\hline 126-791B-5R-CC & 435.0 & 0.219 & A & G & 17 & 0 & 0 & 28 & 29 & 42 & 163 & 0 & 6 & 0 & 0 & 2 & 2 & 3 & 0 & 0 & 6 & 298 \\
\hline 126-791B-9R-CC & 473.3 & 0.251 & A & G & 10 & 1 & 1 & 16 & 14 & 51 & 190 & 0 & 3 & 0 & 0 & 1 & 0 & 5 & 0 & 1 & 4 & 297 \\
\hline 126-791B-11R-CC & 492.6 & 0.267 & C & G & 19 & 0 & 1 & 3 & 62 & 82 & 127 & 0 & 0 & 2 & 0 & 0 & 1 & 0 & 0 & 1 & 2 & 300 \\
\hline 126-791B-15R-CC & 521.7 & 0.311 & A & G & 10 & 0 & 0 & 0 & 35 & 79 & 174 & 0 & 2 & 0 & 0 & 0 & 0 & 0 & 0 & 0 & 2 & 302 \\
\hline 126-791B-18R-CC & 560.3 & 0.336 & A & G & 14 & 0 & 0 & 0 & 96 & 59 & 127 & 0 & 1 & 0 & 0 & 0 & 0 & 0 & 0 & 0 & 3 & 300 \\
\hline 126-791B-2OR-CC & 579.3 & 0.360 & $\mathbf{A}$ & G & 4 & 0 & 0 & 0 & 29 & 21 & 245 & 0 & 0 & 0 & 0 & 0 & 0 & 0 & 0 & 0 & 1 & 300 \\
\hline 126-791B-22R-CC & 598.7 & 0.384 & A & G & 6 & 0 & 0 & 0 & 36 & 15 & 241 & 0 & 1 & 0. & 0 & 0 & 0 & 0 & 0 & 0 & 0 & 299 \\
\hline $126-791 \mathrm{~B}-24 \mathrm{R}-\mathrm{CC}$ & 618.1 & 0.408 & A & G & 1 & 0 & 0 & 0 & 70 & 31 & 195 & 0 & 2 & 0 & 0 & 0 & 0 & 0 & 0 & 0 & 1 & 300 \\
\hline 126-791B-26R-CC & 637.0 & 0.432 & A & G & 4 & 0 & 0 & 0 & 200 & 9 & 86 & 0 & 1 & 0 & 0 & 0 & 0 & 0 & 0 & 0 & 0 & 300 \\
\hline 126-791B-28R-CC & 656.3 & 0.457 & A & G & 0 & 0 & 0 & 0 & 190 & 6 & 103 & 0 & 1 & 0 & 0 & 0 & 0 & 0 & 0 & 0 & 0 & 300 \\
\hline 126-791B-30R-CC & 675.6 & 0.514 & A & G & 0 & 0 & 0 & 0 & 194 & 12 & 93 & 0 & 0 & 0 & 0 & 0 & 0 & 0 & 0 & 0 & 0 & 299 \\
\hline $126-791 \mathrm{~B}-32 \mathrm{R}-\mathrm{CC}$ & 695.0 & 0.572 & A & G & 0 & 0 & 1 & 0 & 196 & 4 & 98 & 0 & 3 & 0 & 0 & 0 & 0 & 0 & 0 & 0 & 0 & 302 \\
\hline 126-791B-34R-CC & 714.3 & 0.629 & A & G & 0 & 0 & 0 & 0 & 195 & 10 & 91 & 0 & 0 & 1 & 0 & 0 & 0 & 0 & 0 & 0 & 0 & 297 \\
\hline 126-791B-37R-CC & 742.8 & 0.714 & A & G & 5 & 2 & 0 & 0 & 59 & 17 & 212 & 0 & 0 & 0 & 0 & 1 & 0 & 1 & 0 & 1 & 2 & 300 \\
\hline 126-791B-39R-CC & 762.1 & 0.771 & A & G & 2 & 0 & 0 & 0 & 3 & 4 & 286 & 1 & 0 & 1 & 0 & 0 & 0 & 0 & 0 & 0 & 0 & 297 \\
\hline 126-791B-41R-3, 107 & 775.8 & 0.818 & A & G & 10 & 0 & 0 & 0 & 172 & 1 & 115 & 0 & 2 & 0 & 1 & 0 & 0 & 0 & 0 & 0 & 0 & 300 \\
\hline 126-791B-43R-CC & 800.7 & 0.901 & A & G & 5 & 0 & 0 & 0 & 191 & 1 & 82 & 0 & 3 & 1 & 16 & 0 & 0 & 0 & 0 & 0 & 0 & 299 \\
\hline 126-791B-45R-CC & 820.0 & 0.966 & A & G & 8 & 0 & 0 & 0 & 37 & 1 & 210 & 0 & 1 & 4 & 37 & 1 & 0 & 0 & 0 & 0 & 1 & 300 \\
\hline $126-791 \mathrm{~B}-47 \mathrm{R}-1,46$ & 830.0 & 0.999 & A & G & 11 & 0 & 1 & 0 & 91 & 0 & 190 & 0 & 0 & 4 & 2 & 0 & 0 & 0 & 0 & 0 & 1 & 300 \\
\hline
\end{tabular}

Note: Abundance: $\mathrm{A}=\mathrm{abundant}, \mathrm{C}=\mathrm{common}$

Preservation: $\mathrm{G}=$ good, $\mathrm{M}=$ moderate

fossil assemblages, therefore, may have been intermittently sampled. More detailed sampling should resolve some of the differences in the abundance patterns.

Preservation of nannofossils is generally good in most Pleistocene samples studied and does not appear to be a major factor in assemblage changes.

Reexamination of the slides reveals that the more prominent relative abundance peaks and minima of the species (based on counts of 300) are readily recognizable from scans of thousands of specimens on each smear slide. Therefore, although the criteria for subdividing the morphotypes of Gephyrocapsa allowed for some overlap in forms, the counts do appear to reflect true relative abundance fluctuations in the various morphotypes.

Uneven distribution of nannofossils on the smear slides (i.e., clumping) tends to obscure the very small Gephyrocapsa, which could affect the magnitude of their abundance peaks recognized from the counts. Large amounts of volcanic ash in the smear slides (mostly above 150 mbsf at Site 790 and above 320 mbsf at Site 791) also make it difficult to see the smaller specimens and could contribute to differences in species abundances. For the intervals with the differing abundance peaks listed above, however, the sediments are mostly carbonate-rich hemipelagics, with little volcanic ash to obscure the nannofossils.

Sites 790 and 791 differ significantly in sediment thickness (Figs. 4 and 5), which is a result of the location of Site 790 on a basement high, and that of Site 791 in a basin (Shipboard Scientific Party, 1990, fig. 7). Site 791 may conceivably have received some of its sediment input from reworking downslope from Site 790. It is difficult to determine the extent of synsedimentary reworking, however, because the nannofossils would not show definite age discrepancies. Reworked nannofossils from distinctly older strata are present but rare throughout these sections (Shipboard Scientific Party, 1990). If significant reworking is the cause of the assemblage differences between sites, it could only have occurred during short intervals of time, because the sections have closely comparable assemblages through most of the last $1 \mathrm{~m} . \mathrm{y}$.

One final factor may be that the differences between the two sites reflect actual differences in the surficial plankton over distances of a few kilometers. Whether this is true or not, a combination of factors listed above could contribute to the observed differences. Because the assemblage patterns of Sites 790 and 791 are similar through most of 
Table 4. Numerical abundances of nannofossil taxa encountered in counts of 300 specimens per sample, Hole 792A.

\begin{tabular}{|c|c|c|c|c|c|c|c|c|c|c|c|c|c|c|c|c|c|c|c|c|}
\hline Sample & 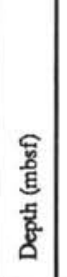 & 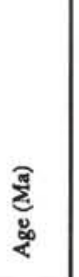 & $\begin{array}{l}8 \\
\frac{8}{8} \\
\frac{5}{8} \\
\frac{8}{<}\end{array}$ & 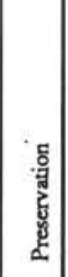 & 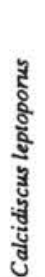 & 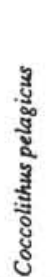 & 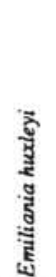 & 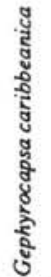 & 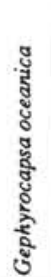 & 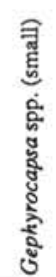 & 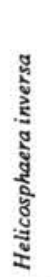 & 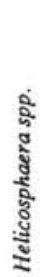 & 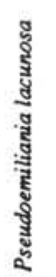 & 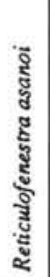 & 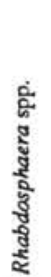 & 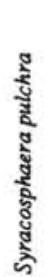 & 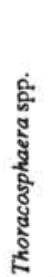 & 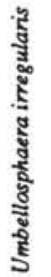 & 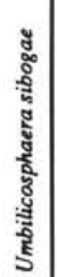 & 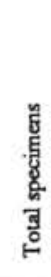 \\
\hline $126-792 \mathrm{~A}-1 \mathrm{H}-1,50$ & 0.5 & 0.005 & $\mathbf{A}$ & G & 15 & 0 & 240 & 5 & 25 & 5 & 0 & 2 & 0 & 0 & 1 & 0 & 1 & 0 & 6 & 300 \\
\hline $126-792 \mathrm{~A}-1 \mathrm{H}-2,42$ & 1.9 & 0.019 & A & G & 1 & 0 & 243 & 19 & 32 & 1 & 0 & 0 & 0 & 0 & 0 & 0 & 0 & 1 & 3 & 300 \\
\hline $126-792 \mathrm{~A}-1 \mathrm{H}-3,48$ & 3.5 & 0.035 & A & G & 5 & 0 & 227 & 19 & 40 & 1 & 1 & 4 & 0 & 0 & 0 & 0 & 0 & 0 & 3 & 300 \\
\hline $126-792 \mathrm{~A}-1 \mathrm{H} \cdot 4,50$ & 5.0 & 0.050 & A & G & 5 & 4 & 180 & 42 & 56 & 6 & 0 & 1 & 0 & 0 & 2 & 1 & 0 & 0 & 3 & 300 \\
\hline $126-792 \mathrm{~A}-1 \mathrm{H}-5,20$ & 6.2 & 0.062 & A & G & 8 & 0 & 254 & 1 & 23 & 11 & 0 & 0 & 0 & 0 & 0 & 0 & 0 & 0 & 3 & 300 \\
\hline $126-792 \mathrm{~A}-1 \mathrm{H}-\mathrm{CC}$ & 9.7 & 0.096 & A & G & 9 & 0 & 42 & 58 & 84 & 91 & 0 & 3 & 0 & 0 & 1 & 0 & 2 & 0 & 9 & 299 \\
\hline $126-792 \mathrm{~A}-2 \mathrm{H}-\mathrm{CC}$ & 15.6 & 0.154 & C & M & 6 & 1 & 22 & 16 & 66 & 184 & 0 & 1 & 0 & 0 & 1 & 0 & 0 & 0 & 3 & 300 \\
\hline $126-792 \mathrm{~A}-3 \mathrm{H}-1,63$ & 19.7 & 0.196 & A & G & 14 & 1 & 104 & 32 & 87 & 57 & 0 & 2 & 0 & 0 & 1 & 0 & 0 & 0 & 2 & 300 \\
\hline $126-792 \mathrm{~A}-3 \mathrm{H}-3,86$ & 22.9 & 0.227 & A & G & 1 & 0 & 29 & 239 & 8 & 22 & 0 & 0 & 0 & 0 & 1 & 0 & 0 & 0 & 0 & 300 \\
\hline $126-792 \mathrm{~A}-3 \mathrm{H}-5,61$ & 25.7 & 0.255 & A & G & 0 & 0 & 28 & 233 & 3 & 35 & 0 & 0 & 0 & 0 & 0 & 0 & 0 & 0 & 1 & 300 \\
\hline $126-792 \mathrm{~A}-3 \mathrm{H}-6,42$ & 27.0 & 0.268 & A & G & 4 & 0 & 3 & 259 & 6 & 26 & 0 & 1 & 0 & 0 & 1 & 0 & 0 & 0 & 0 & 300 \\
\hline 126-792A-3H-CC & 28.4 & 0.293 & A & G & 3 & 1 & 0 & 230 & 8 & 58 & 0 & 0 & 0 & 0 & 0 & 0 & 0 & 0 & 0 & 300 \\
\hline $126-792 \mathrm{~A}-4 \mathrm{H}-1,40-41$ & 28.8 & 0.304 & A & G & 4 & 1 & 1 & 194 & 5 & 93 & 0 & 0 & 0 & 0 & 0 & 0 & 0 & 0 & 2 & 300 \\
\hline $126-792 \mathrm{~A}-4 \mathrm{H}-3,40-41$ & 31.8 & 0.382 & A & G & 4 & 0 & 0 & 274 & 2 & 19 & 0 & 1 & 0 & 0 & 0 & 0 & 0 & 0 & 0 & 300 \\
\hline $126-792 \mathrm{~A}-4 \mathrm{H}-\mathrm{CC}$ & 37.8 & 0.493 & A & M-G & 2 & 0 & 0 & 258 & 4 & 36 & 0 & 0 & 0 & 0 & 0 & 0 & 0 & 0 & 0 & 300 \\
\hline $126-792 \mathrm{~A}-5 \mathrm{H}-3,40-41$ & 41.2 & 0.531 & A & G & 0 & 0 & 1 & 239 & 1 & 57 & 0 & 0 & 2 & 0 & 0 & 0 & 0 & 0 & 0 & 300 \\
\hline $126-792 \mathrm{~A}-5 \mathrm{H}-6,40-42$ & 45.7 & 0.582 & A & G & 2 & 0 & 0 & 269 & 8 & 19 & 0 & 1 & 0 & 0 & 0 & 0 & 0 & 0 & 1 & 300 \\
\hline $126-792 \mathrm{~A}-5 \mathrm{H}-\mathrm{CC}$ & 47.2 & 0.598 & A & G & 3 & 1 & 0 & 272 & 15 & 6 & 0 & 3 & 0 & 0 & 0 & 0 & 0 & 0 & 0 & 300 \\
\hline $126-792 \mathrm{~A}-7 \mathrm{H}-1,41-42$ & 57.0 & 0.708 & A & G & 1 & 0 & 0 & 41 & 38 & 219 & 0 & 0 & 1 & 0 & 0 & 0 & 0 & 0 & 0 & 300 \\
\hline $126-792 \mathrm{~A}-7 \mathrm{H}-2,41-42$ & 58.5 & 0.724 & A & G & 6 & 0 & 1 & 53 & 30 & 206 & 0 & 0 & 0 & 0 & 0 & 0 & 1 & 0 & 3 & 300 \\
\hline 126-792A-7H-CC & 66.0 & 0.783 & A & G & 0 & 0 & 0 & 19 & 17 & 264 & 0 & 0 & 0 & 0 & 0 & 0 & 0 & 0 & 0 & 300 \\
\hline $126-792 \mathrm{~A}-8 \mathrm{H}-1,105-106$ & 67.1 & 0.792 & A & G & 2 & 0 & 0 & 6 & 11 & 280 & 0 & 0 & 0 & 0 & 0 & 0 & 0 & 0 & 1 & 300 \\
\hline $126-792 \mathrm{~A}-8 \mathrm{H}-2,85-86$ & 68.3 & 0.801 & A & G & 1 & 0 & 0 & 18 & 29 & 250 & 0 & 1 & 0 & 0 & 0 & 1 & 0 & 0 & 0 & 300 \\
\hline $126-792 \mathrm{~A}-9 \mathrm{H}-1,64-65$ & 76.2 & 0.861 & A & G & 3 & 0 & 0 & 103 & 26 & 164 & 0 & 1 & 0 & 3 & 0 & 0 & 0 & 0 & 0 & 300 \\
\hline $126-792 \mathrm{~A}-9 \mathrm{H}-3,39-40$ & 79.0 & 0.883 & A & G & 1 & 0 & 0 & 57 & 7 & 229 & 0 & 0 & 0 & 5 & 0 & 0 & 0 & 0 & 1 & 300 \\
\hline 126-792A-9H-CC & 85.3 & 0.940 & A & G & 0 & 0 & 0 & 91 & 6 & 190 & 0 & 0 & 2 & 11 & 0 & 0 & 0 & 0 & 0 & 300 \\
\hline $126-792 \mathrm{~A}-10 \mathrm{H}-1,25-26$ & 85.5 & 0.942 & A & G & 0 & 0 & 0 & 24 & 27 & 244 & 0 & 3 & 0 & 1 & 0 & 0 & 0 & 0 & 0 & 299 \\
\hline $126-792 \mathrm{~A}-10 \mathrm{H}-3,50-51$ & 88.8 & 0.978 & A & G & 3 & 0 & 0 & 24 & 17 & 256 & 0 & 0 & 0 & 0 & 0 & 0 & 0 & 0 & 0 & 300 \\
\hline
\end{tabular}

Note: Abundance: $A=a b u n d a n t, C=c o m m o n$

Preservation: $\mathrm{G}=$ good, $\mathrm{M}=$ moderate

their sequence, we think that the few differences are most likely a result of uneven sample spacing.

These two sites may show a lower limit to the similarity that could be expected in comparing nannofossil assemblages from different localities with similar paleoenvironments and geologic conditions. Correlations between sections of greater distance and greater dissimilarity of geologic and paleoenvironmental setting should, therefore, be expected to show greater dissimilarity in nannofossil assemblages than Sites 790 and 791.

Site 792 also shows a closely similar distribution of nannofossils to Sites 790 and 791, even though it is more distant from the other two sites and has a different sedimentation history (Fig. 6). Site 792 does not show the increase in $G$. oceanica between 0.55 and $0.6 \mathrm{Ma}$, nor the peak abundance of small Gephyrocapsa at $0.4 \mathrm{Ma}$; it does show a later increase in $G$. oceanica (0.2 Ma) compared with Sites 790 and 791 ( 0.25 to $0.35 \mathrm{Ma})$.

\section{Comparison with Matsuoka and Okada (1989)}

Our Pleistocene assemblages can be compared with those recognized by Matsuoka and Okada (1989, Assemblages A through E) from a subtropical piston core from the West Mariana Ridge (Fig. 7). In that study, six assemblages were recognized that spanned from 0 to $1.3 \mathrm{Ma}$. One primary difference between our assemblages and those of Matsuoka and Okada (1989) is the relative scarcity of P. lacunosa at the Leg 126 sites compared with the Mariana piston core. This may be primarily a result of differing environments, with $P$. lacunosa preferring more tropical and subtropical conditions than temperate conditions.

Assemblage 1 and Assemblage A are both characterized by a dominance of $E$. huxleyi and have common to abundant $G$. oceanica and common C. leptoporus.

Both Assemblage 2 and Assemblage B contain common E. huxleyi and common G. oceanica. Gephyrocapsa caribbeanica decreases in abundance dramatically within this assemblage at the Leg 126 sites, but the corresponding morphotype in the Mariana core (medium G. oceanica [diagonal]) remains abundant. Also, U. sibogae is rare at the Leg 126 sites and abundant in the Mariana core. One final difference is that small Gephyrocapsa are abundant to dominant in this interval at the Leg 126 sites, but form only a minor component of Assemblage B.

Assemblage 3 compares closely with Assemblage C. We recognize a dominance in this interval of $G$. caribbeanica, whereas Matsuoka and Okada (1989) recognized a dominance of medium-sized G. oceanica (diagonal). Matsuoka and Okada (1990) renamed this form as Gephyrocapsa sp. D and stated that the early forms of this species, within Assemblage 3 time (approximately $0.6-0.275 \mathrm{Ma}$ ), closely resemble what other authors have called $G$. caribbeanica, with small holes and high crossbar angles. Examination of our samples reveals that our $G$. caribbeanica in Assemblage 3 do have high crossbar angles (Plate 1, Figs. $7-8$ ), in contrast to the G. caribbeanica in the lower part of Assemblage 4. The G. caribbeanica in the upper part of Assemblage 4, above the abundance peak of small Gephyrocapsa, also predominantly have high crossbar angles, though a small number have low crossbar 


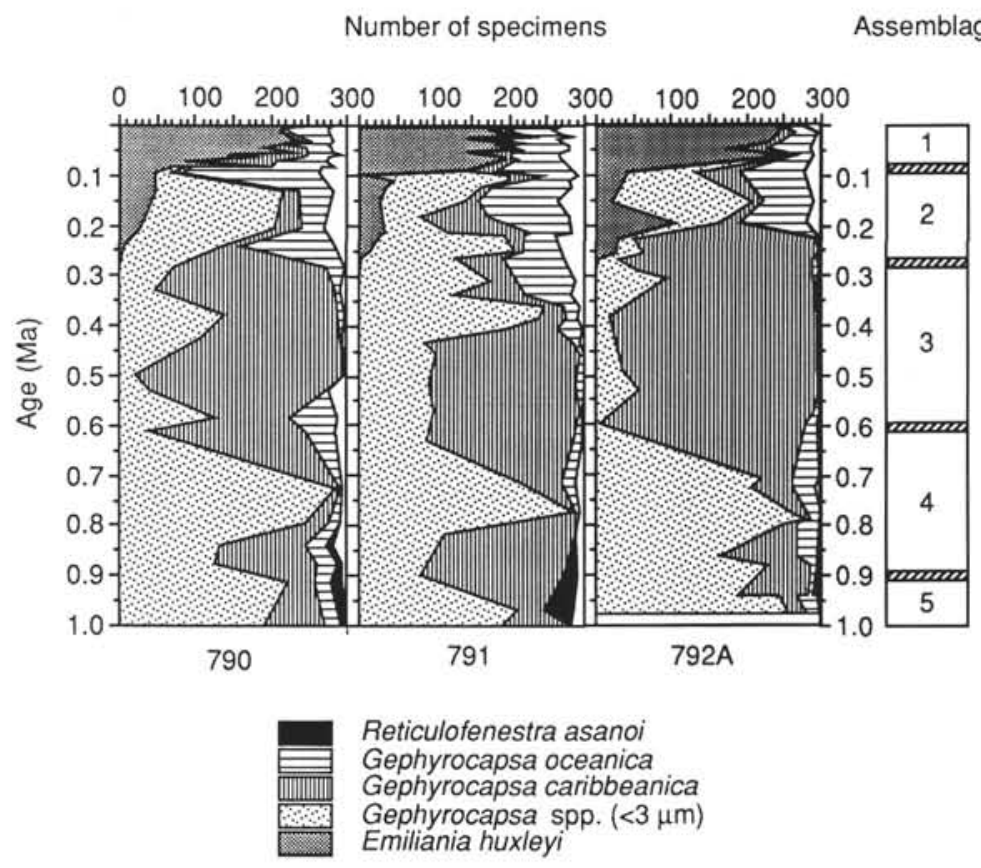

Figure 2. Abundances (based on counts of 300 specimens per sample) through time of selected nannofossil species at Sites 790, 791, and 792, and the five nannofossil assemblages recognized at each site.

angles. This confirms the observations of Matsuoka and Fujioka (this volume) that the upper range of one population of Gephyrocapsa (Gephyrocapsa sp. C) overlaps the beginning of the range of another population (Gephyrocapsa sp. D).

Assemblage 4 and Assemblage D are very similar in composition. Both assemblages contain common to abundant medium-sized Gephyrocapsa in the lower and upper parts, and dominant small Gephyrocapsa in the middle part. In addition, $R$. asanoi is common in the lower part, and large $G$. oceanica are common in the upper part. Matsuoka and Okada $(1989,1990)$ recognized morphotypes of medium and large Gephyrocapsa in this interval with low-angle crossbars relative to the short axis of the placolith, which they termed G. oceanica (vertical) and Gephyrocapsa sp. C, respectively. Examination of $G$. caribbeanica and $G$. oceanica in the lower part of Assemblage 4 shows that they also have low-angle crossbars (Plate 1, Figs. 1-4), similar to those recognized by Matsuoka and Okada $(1989,1990)$. Rio (1982) also recognized morphotypes of Gephyrocapsa with low crossbar angles that first occur above the "small Gephyrocapsa Zone" at about $0.9 \mathrm{Ma}$ in the Mediterranean Sea.

The dominant peak of small Gephyrocapsa that occurred between 0.8 and $0.6 \mathrm{Ma}$ in Leg 126 sites corresponds to similar peaks recognized in the Mariana core and at Site 709 in the tropical Indian Ocean (Matsuoka and Okada, 1989, 1990). Matsuoka and Okada (1989) determined that this abundance peak was composed predominantly of a form they called $G$. protohuxleyi var. A. Matsuoka and Fujioka (this volume) further subdivided the small Gephyrocapsa complex into five component species, based on transmission electron microscope analysis. Although we do not subdivide the small Gephyrocapsa complex, our abundance peak at Site 790 between 0.8 and 0.6 Ma (235 and 255 mbsf) (Fig. 4) is also recognized by Matsuoka and Fujioka (this volume) and is composed of several individual abundance peaks of different small Gephyrocapsa species. This peak abundance does not seem to have been affected greatly by paleoenvironmental conditions, as it is recognized in temperate (Leg 126), subtropical (Mariana core), and tropical (Site 709) regions.
Our Assemblage 5 corresponds in time to the latest part of Matsuoka and Okada's (1989) Assemblage E. However, Assemblage 5 contains dominant small Gephyrocapsa and common G. caribbeanica, whereas Assemblage E has almost no Gephyrocapsa. One shared feature is the common occurrence of $R$. asanoi (Reticulofenestra sp. A of Matsuoka and Okada, 1989). The dominance of $P$. lacunosa, $C$. leptoporus, and Umbilicosphaera sibogae in Assemblage E probably reflects different environmental conditions between the more subtropical Mariana core and the more temperate Leg 126 cores. This interpretation is supported by the studies of Honjo and Okada (1974) and Honjo (1977), which outlined latitudinal zones in the Pacific based on water column samples of recent coccoliths. They recognized a Central North zone from about $5^{\circ}$ to $30^{\circ} \mathrm{N}$, and a Transitional zone from about $30^{\circ}$ to $45^{\circ} \mathrm{N}$. Umbilicosphaera sibogae is common in the Central North zone, but is almost absent in the Transitional zone. This distribution is similar to its reported abundance in the Mariana core, located in the Central North zone, and its scarcity at the Leg 126 sites, located in the Transitional zone.

Geitzenauer et al. (1977) also show distributions of $U$. sibogae (their $U$. mirabilis) from surface sediment samples that reflect environmental differences between the Mariana core region and the Leg 126 region. Care must be taken to extrapolate recent coccolith distribution patterns to $1.0 \mathrm{Ma}$, especially because $P$. lacunosa is no longer extant, and because $E$. huxleyi did not exist at $1.0 \mathrm{Ma}$. Some similarities between Holocene and Pleistocene assemblages should be expected, however, and our results appear to reflect some latitudinal differences in the middle Pleistocene assemblages.

\section{Comparison with Matsuoka and Okada (1990)}

Matsuoka and Okada (1990) analyzed Pleistocene assemblages from Site 709 in the tropical Indian Ocean. Their morphometric analysis of Gephyrocapsa revealed several independent evolutionary lineages arising among larger forms of the genus. Although the morphologies of the different lineages overlap considerably, their 

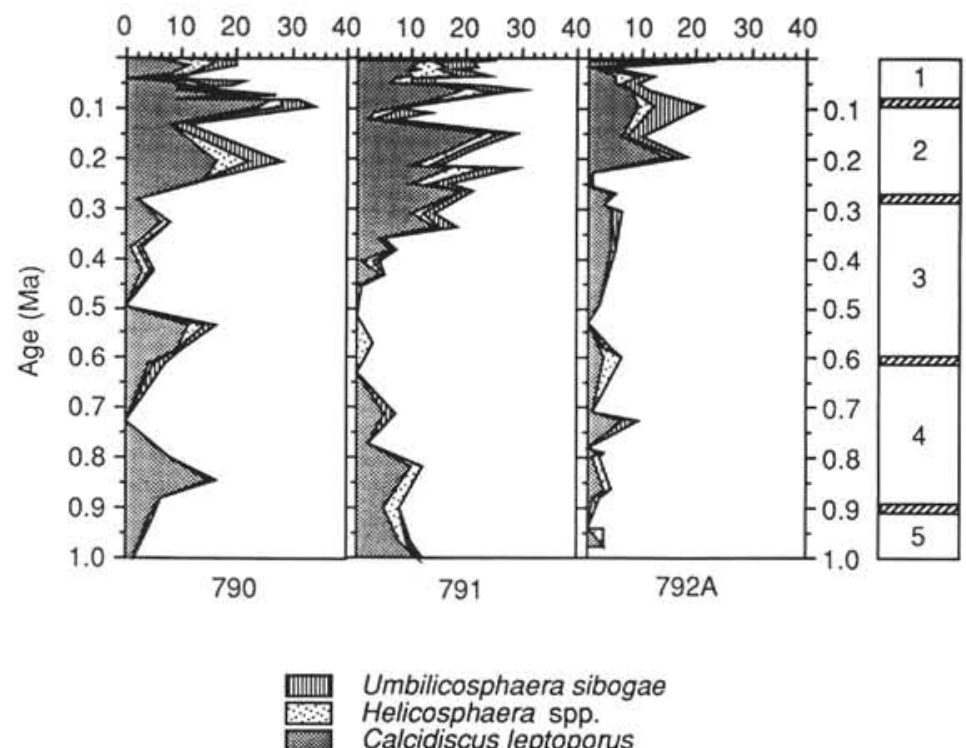

Figure 3. Abundances (based on counts of 300 specimens per sample) through time of selected nannofossil species at Sites 790, 791, and 792, and the five nannofossil assemblages recognized at each site.

stratigraphic ranges are distinct, allowing them to be distinguished from each other. In the time span studied at the Leg 126 sites $(<1.0$ $\mathrm{Ma}$ ), only two of these lineages (Gephyrocapsa sp. C and Gephyrocapsa sp. D) would be expected to be seen at Sites 790, 791, and 792. Gephyrocapsa sp. C (0.92-0.55 Ma) first appears as small- to mediumsized, small-holed forms with low-angle crossbars that develop into large, large-holed forms with low-angle crossbars. They are abundant in their early stage and decrease in abundance in their later stage.

At the Leg 126 sites, $G$. caribbeanica between 1.0 and $0.7-0.6 \mathrm{Ma}$, and $G$. oceanica between 1.0 and $0.55 \mathrm{Ma}$ are morphologically equivalent to Gephyrocapsa sp. C(Plate 1, Figs. 1-4) and show virtually synchronous distributions compared with the Site 709 material (Fig. 7). Gephyrocapsa

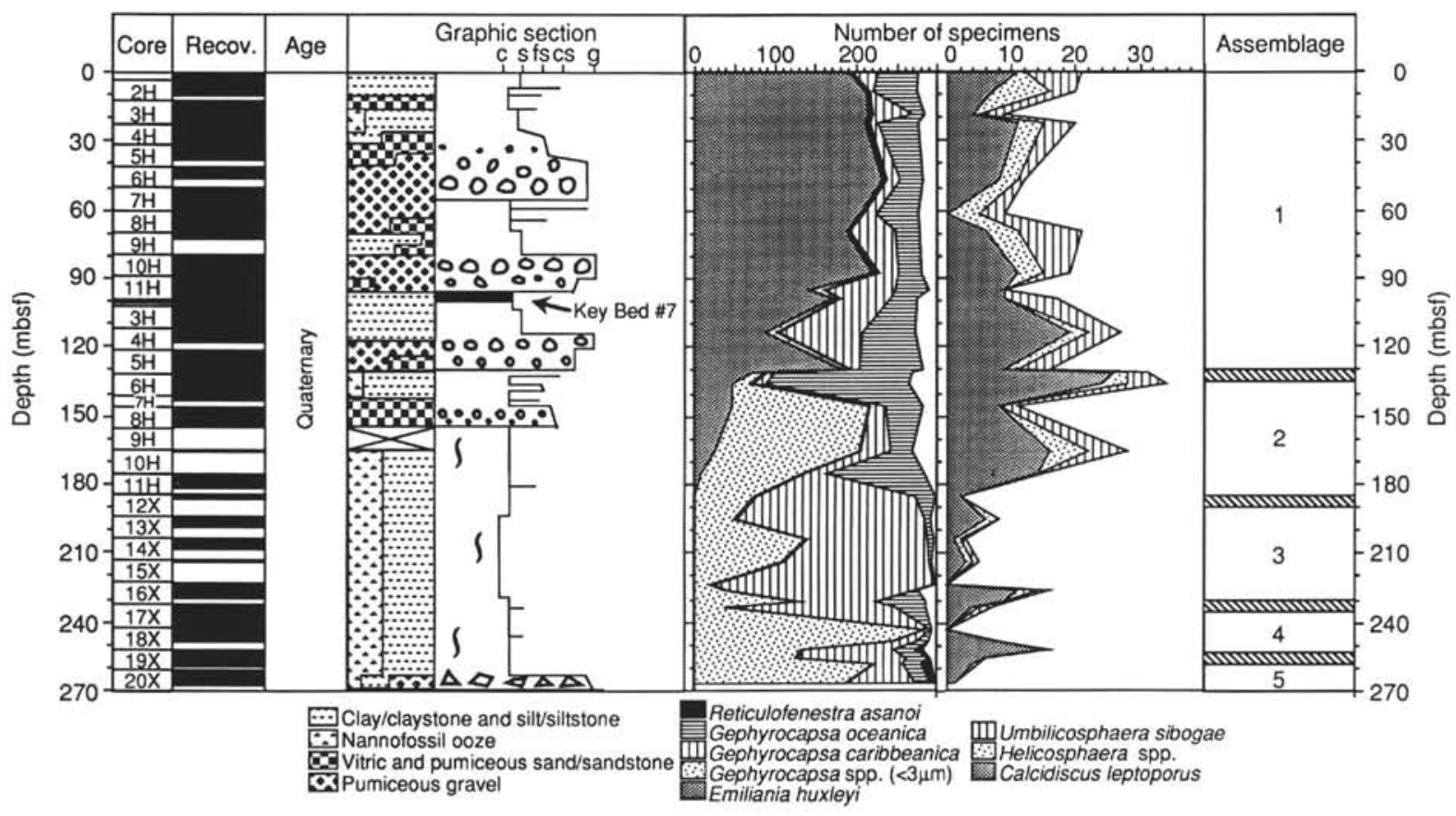

Figure 4. Core numbers, core recovery, age, graphic lithology, and abundances (based on counts of 300 specimens per sample) vs. depth of selected nannofossil species at Site 790. 


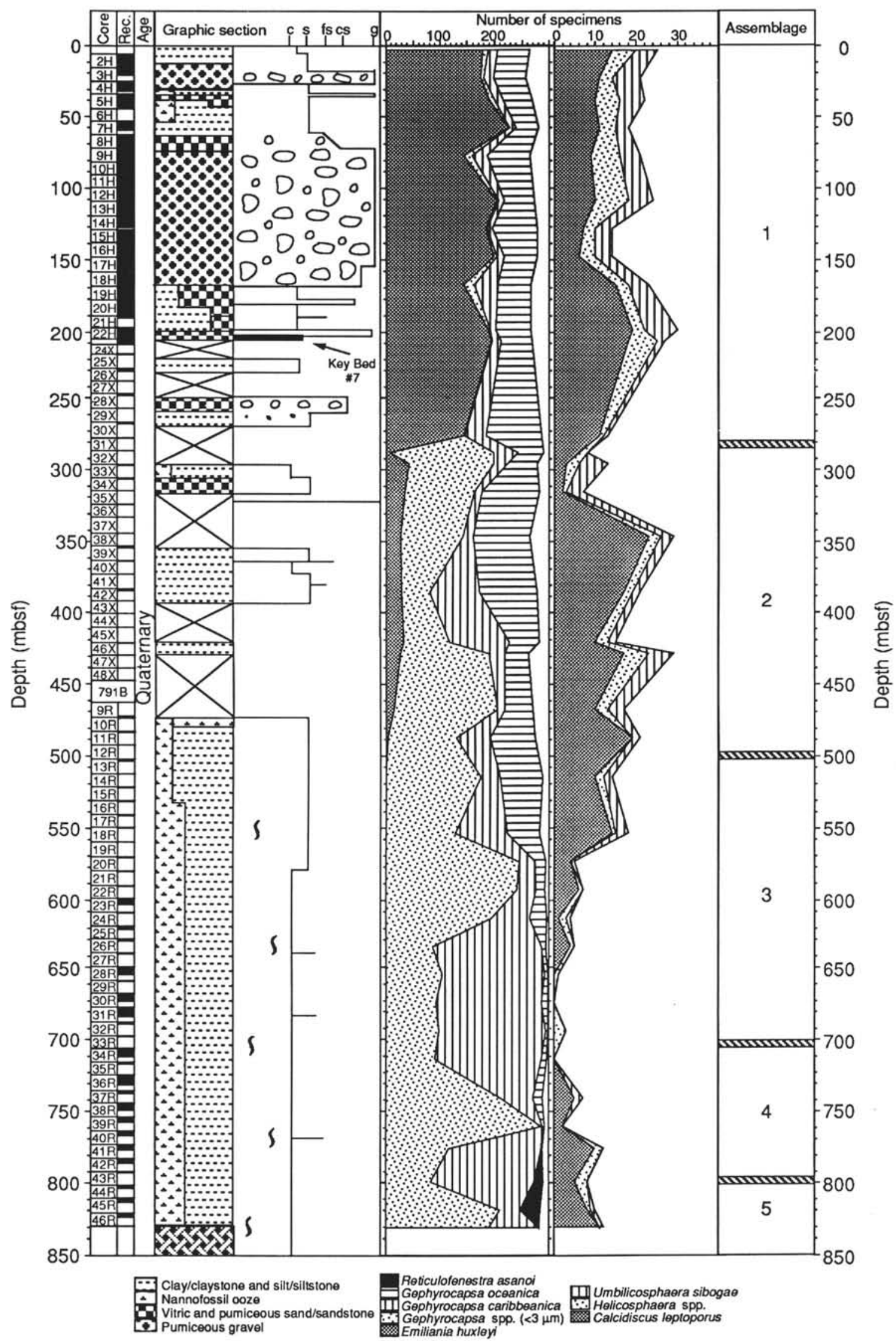

Figure 5. Core numbers, core recovery, age, graphic lithology, and abundances (based on counts of 300 specimens per sample) vs. depth of selected nannofossil species at Site 791. 

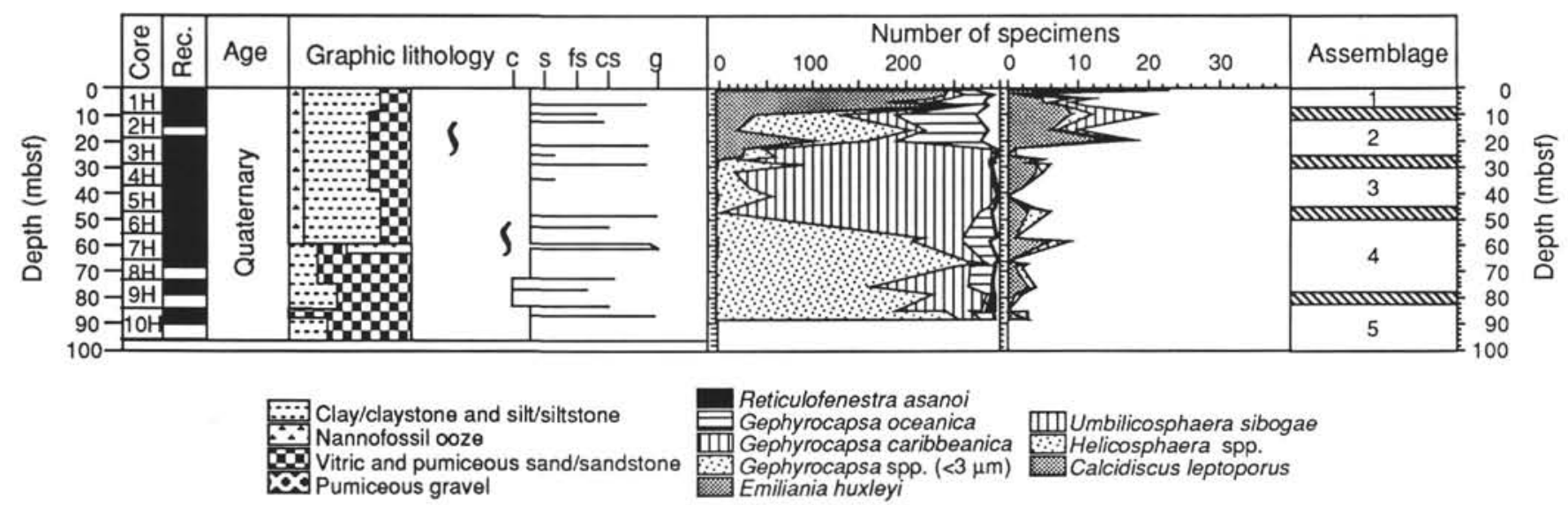

Figure 6. Core numbers, core recovery, age, graphic lithology, and abundances (based on counts of 300 specimens per sample) vs. depth of selected nannofossil species at Site 792.

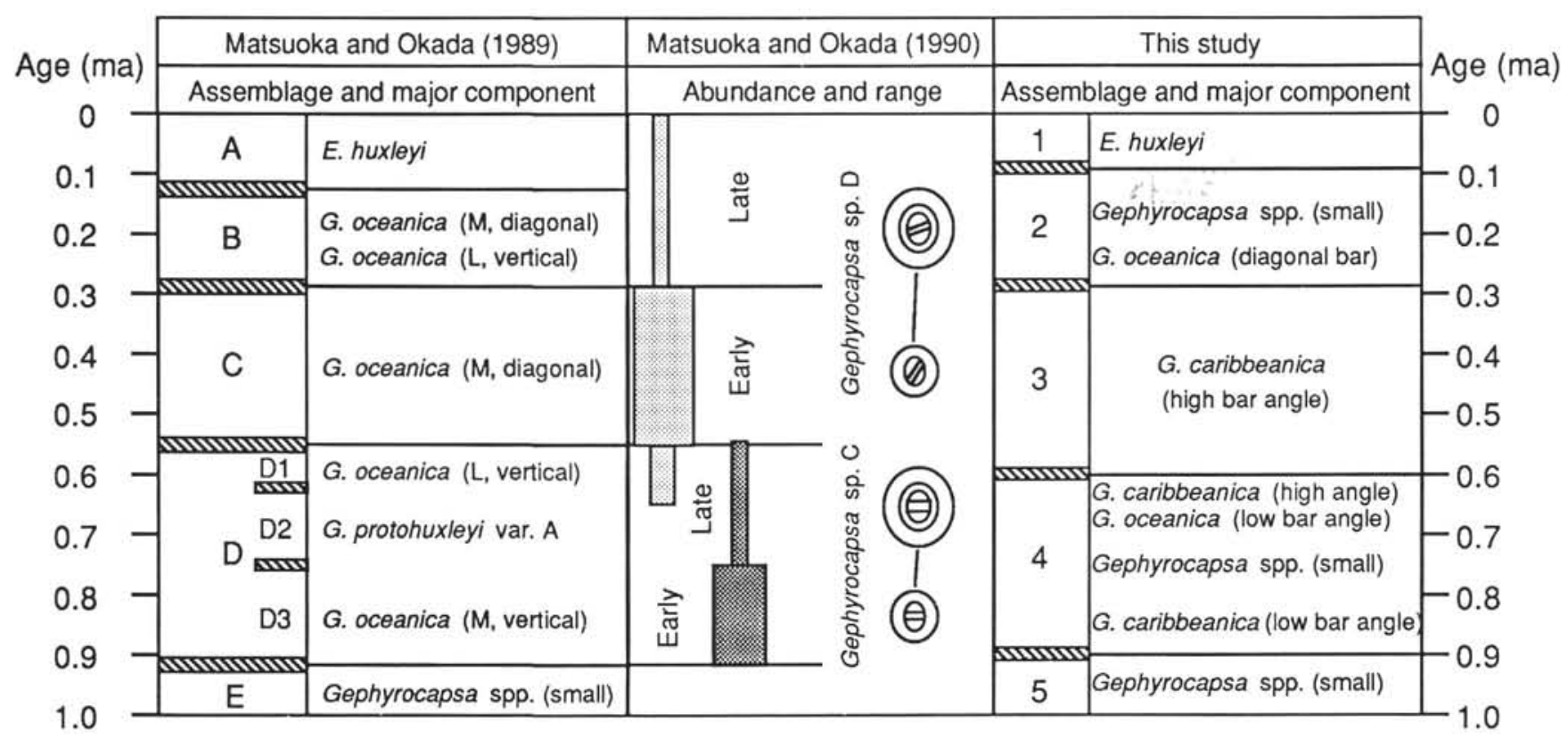

Figure 7. Comparison of nannofossil assemblages and morphotypes of Gephyrocapsa recognized by Matsuoka and Okada (1989) for the subtropical western Pacific, by Matsuoka and Okada (1990) for Site 709 in the equatorial Indian Ocean, and in this study.

sp. D (about $0.7 \mathrm{Ma}$ to Holocene) first appears in abundance with small, small- holed forms with very high-angle crossbars, and develops into larger, less abundant forms with larger holes and moderate angle crossbars. Our G. caribbeanica from between 0.7 and $0.6 \mathrm{Ma}$ to Holocene, and G. oceanica from $0.55 \mathrm{Ma}$ to Holocene are morphologically equivalent to Gephyrocapsa sp. D (Plate 1, Figs. 5-8; Plate 2, Figs. 3-4) and also show almost a synchronous distribution compared with the Site 709 material.

\section{Comparison with Gartner (1977)}

Gartner (1977) erected seven zones for the Pleistocene, five of which occur completely or partially within the last $1.0 \mathrm{~m}$.y. Four of these zones are bounded by widely recognized datums (LO of $P$. lacunosa, FO of E. huxleyi, and OA of E. huxleyi) and are also observed in the Leg 126 cores. The "small Gephyrocapsa Zone" has an upper boundary based on the last dominant occurrence of small
Gephyrocapsa, at about 0.92 Ma. At Sites 790, 791, and 792, small Gephyrocapsa have several dominance peaks, one of which occurs between 1.0 and $0.9 \mathrm{Ma}$. This may be interpreted to correspond to the upper part of Gartner's "small Gephyrocapsa Zone" and has a roughly synchronous upper boundary with that reported by Gartner (1977).

\section{OLIGOCENE AND MIOCENE}

\section{Oligocene}

Oligocene sediments recovered at Sites 787, 792, and 793 contain poor to well preserved nannofossils with intermittent zones barren of nannofossils. The depositional water depths of the Leg 126 sites during the Oligocene were between 2 and 4 km (Taylor, Fujioka, et al., 1990), above the reported carbonate compensation depth (CCD) for that time period (van Andel, 1975). The zones of poor preservation, therefore, are probably caused by postdepositional dissolution that result from diagenetic changes in the volcaniclastic sediments. 
Species diversity is moderate in the Oligocene, and the assemblages typically contain common to abundant Cyclicargolithus floridanus and few to common Reticulofenestra bisecta and Discoaster deflandrei (Tables 5-7). Warm-water taxa such as discoasters, sphenoliths, and helicosphaerids (Wei and Wise, 1990), and cold-water taxa such as chiasmoliths are present but not particularly abundant, indicating a temperate paleoenvironment for these sites during the Oligocene.

The oldest sediments recovered during Leg 126 were of early Oligocene age at Site 793. These sediments occur below the FO of Sphenolithus ciperoensis (Sample 126-793B-54R-CC) and are assigned to Zones CP17-CP18 of Okada and Bukry (1980). One questionable specimen of Reticulofenestra umbilica was observed in Sample 126-793B-81R-1, $86-87 \mathrm{~cm}$, which could possibly indicate assignment of this sample to Subzone CP16c; this specimen, however, could have been reworked from older rocks on the frontal arc or outer arc highs. The rest of the Oligocene sections lie above the FO of S. ciperoensis and are assigned to Zone CP19. The LO of Sphenolithus distentus is used to subdivide this zone into Subzones CP19a and CP19b. This datum is tentative, however, because of the rare and sporadic occurrence of $S$. distentus in its upper range. The scarcity of $S$. ciperoensis renders its LO datum of little value (see "Chronostratigraphy" section, below).

Taylor, Fujioka, et al. (1990) recognize the base of the third normal interval in Subchron C6C (24.21 Ma) in the upper part of Hole 787B. This assignment is tentative (see discussion below, in "Chronostratigraphy" section), but if true would indicate that Site 787 contains more of the upper Oligocene than Sites 792 and 793. The presence of the upper Oligocene form Discoaster calculosus (see Perch-Nielsen, 1985) from Samples 126-787B-6R-1, 87-88 cm, to -11R-CC in Hole 787B (Table 5), which was not observed at Sites 792 and 793, supports the idea that much of the uppermost Oligocene is present in Hole 787B. Extrapolation upward of the sedimentation rate in Hole 787B, based on magnetostratigraphy (Table 8 ), to the uppermost Oligocene sample (126-787B-6R-1, 87-88 cm) gives a value of $23.67 \mathrm{Ma}$, which is roughly equivalent to the age of the Oligocene/Miocene boundary (based on the LO of $R$. bisecta at $23.7 \mathrm{Ma}$, Berggren et al., 1985a).

Subchrons C6AA, C6B, C6C, and C7 are not recognized at Site 792, which indicates that the uppermost Oligocene and lowest Miocene sediments are missing from Site 792 (Taylor, Fujioka, et al., 1990). The lowest Miocene recognized in Hole 792E is Subzone CN1c in Sample 126-792E-28R-CC (based on the FO of Discoaster druggii). This indicates an age of 23.2 Ma or younger (Berggren et al., 1985b) for this sample. Immediately below this, in Sample 126-792E-29R-1, 106-109cm, thenannofossil assemblage istypical of the upper Oligocene, with $R$. bisecta, $C$. floridanus, $D$. deflandrei, and Clausicoccus fenestratus. A fault zone was identified in Section 126-792E$29 \mathrm{R}-1$, which may have contributed to the hiatus recognized by the magnetostratigraphy (Taylor, Fujioka, et al., 1990). The LO of R. bisecta at Site 792 as reported in Taylor, Fujioka, et al. (1990) is not reliable for calculating sedimentation rate curves for this interval or for determining the Oligocene/Miocene boundary because $R$. bisecta ranges into the Miocene in this section (Table 9). If we instead assume that the upperOligocene sedimentation rate was relatively constant, and extrapolate upward the sedimentation rate from between Chrons C9 and C8 (Table 8), we derive an age of about 26.7 Ma for Sample 126-792E-29R-1, 106-109 cm. This suggests that up to 3 m.y. of the uppermost Oligocene sediments might be missing at Site 792.

The age-depth curve for Site 793 (Taylor, Fujioka, et al., 1990) does not indicate a hiatus across the Oligocene/Miocene boundary, although there is an interval barren of calcareous nannofossils separating upper Oligocene sediments in Sample 126-793B-21R-CC from lower Miocene (Subzone CN1c) sediments in Sample 126-793B-18R-4, 23-25 cm. Interpolation of the Oligocene sedimentation rate between the first and second normal intervals in Chron C8 (Table 8) gives an age of $27.06 \mathrm{Ma}$ for Sample 126-793B-21R-CC. This is well below the top of Zone CP19 (25.2 Ma, Berggren et al., 1985a). Therefore, the last 3.3 m.y. of the Oligocene is either missing or is contained within the barren interval at Site 793 , and we cannot distinguish the Oligocene/Miocene boundary from the nannofossil biostratigraphy.

\section{Miocene}

Miocene sediments at Sites 792 and 793 contain moderate to wellpreserved nannofossils (Plate 4), and species diversity is much higher than in the Oligocene (Tables 9 and 10). The middle and upper Miocene at Site 792 contains many species of Discoaster and Helicosphaera. As discussed above, $C$. abisectus is considered herein to represent large specimens $(>9 \mu \mathrm{m})$ of $C$. floridanus and was not recorded separately. We observed common to abundant large specimens occurring up to the $\mathrm{LO}$ of $C$. floridanus in the middle Miocene (Site 792, 338.3 mbsf, 11.7 Ma). No distinct drop in abundance of the larger forms was observed by which we could distinguish Okada and Bukry's (1980) Subzone CNla. Xu and Wise (in press) also report $C$. abisectus to occur commonly up to the $\mathrm{LO}$ of $C$. floridanus at nearby Site 782 .

The LO of $R$. bisecta appears to be a consistent datum in many areas, occurring between 23.5 (Xu and Wise, in press) and $24.0 \mathrm{Ma}$ (Wei and Wise, 1989). At Sites 792 and 793, R. bisecta occurs throughout the upper Oligocene, but it also overlaps with Discoaster druggii and Sphenolithus heteromorphus in the lower Miocene. Similar rare occurrences in the lower Miocene have been recorded by Okada (1980) on the Daito Ridge (Site 445) and by Fornaciari et al. (1990; fig. 7) in the tropical Indian Ocean (Site 711). As with these other reported occurrences of $R$. bisecta, we consider these occurrences within the Miocene to be most likely a result of reworking.

Sites 792 and 793 contain Subzone CN1c, based on the presence of Discoaster druggii and the absence of Sphenolithus belemnos (Tables 9 and 10). This subzone is characterized by essentially the same assemblage as that of the upper Oligocene, with the addition of $D$. druggii, and the appearance within the interval of small Reticulofenestra pseudoumbilica and rare Discoaster variabilis. Above this subzone, both Sphenolithus belemnos and Sphenolithus heteromorphus have a common first occurrence. The base of Zone CN2 is defined on the FO of S. belemnos, whereas the base of Zone $\mathrm{CN} 3$ is defined on the FO of $S$. heteromorphus. This means that all of the $S$. belemnos Zone (Zone CN2) is missing at both sites.

At Site 792, S. heteromorphus does not range above the LO of $S$. belemnos, and the FO of C. macintyrei (in Sample 126-792E-23R-CC) is just above the LO of both sphenolith species. Perch-Nielsen (1985) reported that $S$. belemnos sometimes overlaps with $S$. heteromorphus in the lower part of Zone CN3. The absence of an interval that contains $S$. heteromorphus and does not contain $S$. belemnos indicates that part of Zone CN3 is missing at Site 792. The absence of an interval that contains both $S$. heteromorphus and C. macintyrei indicates that Zone $\mathrm{CN} 4$ is also missing at Site 792.

At Site 793, the interval that contains $S$. heteromorphus (Sample 126-793B-12R-CC) and is below the first consistent occurrence of Calcidiscus macintyrei (Samples 126-793B-14R-CC to -10R-CC) is assigned to Zone CN3. The interval from Samples 126-793B-10R-CC to $-2 \mathrm{R}-\mathrm{CC}$ contains both $S$. heteromorphus and $C$. macintyrei and does not contain Discoaster kugleri; it is assigned to Zone CN4. The separation of Zones $\mathrm{CN} 3$ and $\mathrm{CN} 4$ at this site may be questionable, however, because of a rare occurrence of $C$. macintyrei in Sample 126-793B-14R-CC. Furthermore, Discoaster deflandrei does not show a significant decrease in abundance within this interval, and is also not useful for subdividing Zones CN3 and CN4.

At Site 792, the interval between the LO of S. heteromorphus (Sample 126-792E-24R-1, 46-47 cm) and the FO of D. kugleri (Sample 126792E-20R-CC) is assigned to Subzone CN5a. Cyclicargolithus floridanus ranges up to near the top of this interval (Sample 126-792E-22R-1, $40-41 \mathrm{~cm}$ ). Subzone CN5b occurs from the FO of D. kugleri (Sample 126-792E-20R-CC) to Sample 126-792E-19R-1, 38-39 cm. Zone CN6 ranges from the FO of Catinaster coalitus in Sample 126-792E-18R-CC to Sample 126-792E-17R-1,40-41 cm. Zone CN7 is marked by the range of Discoaster hamatus from Samples 126-792E-16R-CC to -15R-2, $39-40 \mathrm{~cm}$. Catinaster calyculus has the same range as D. hamatus in Hole 792E. It is uncertain whether Subzone CN7a is missing in this section because of a hiatus or because $C$. calyculus actually ranges lower 
Table 5. Range chart of relative abundances of nannofossil species encountered in Oligocene sediments, Hole 787B.

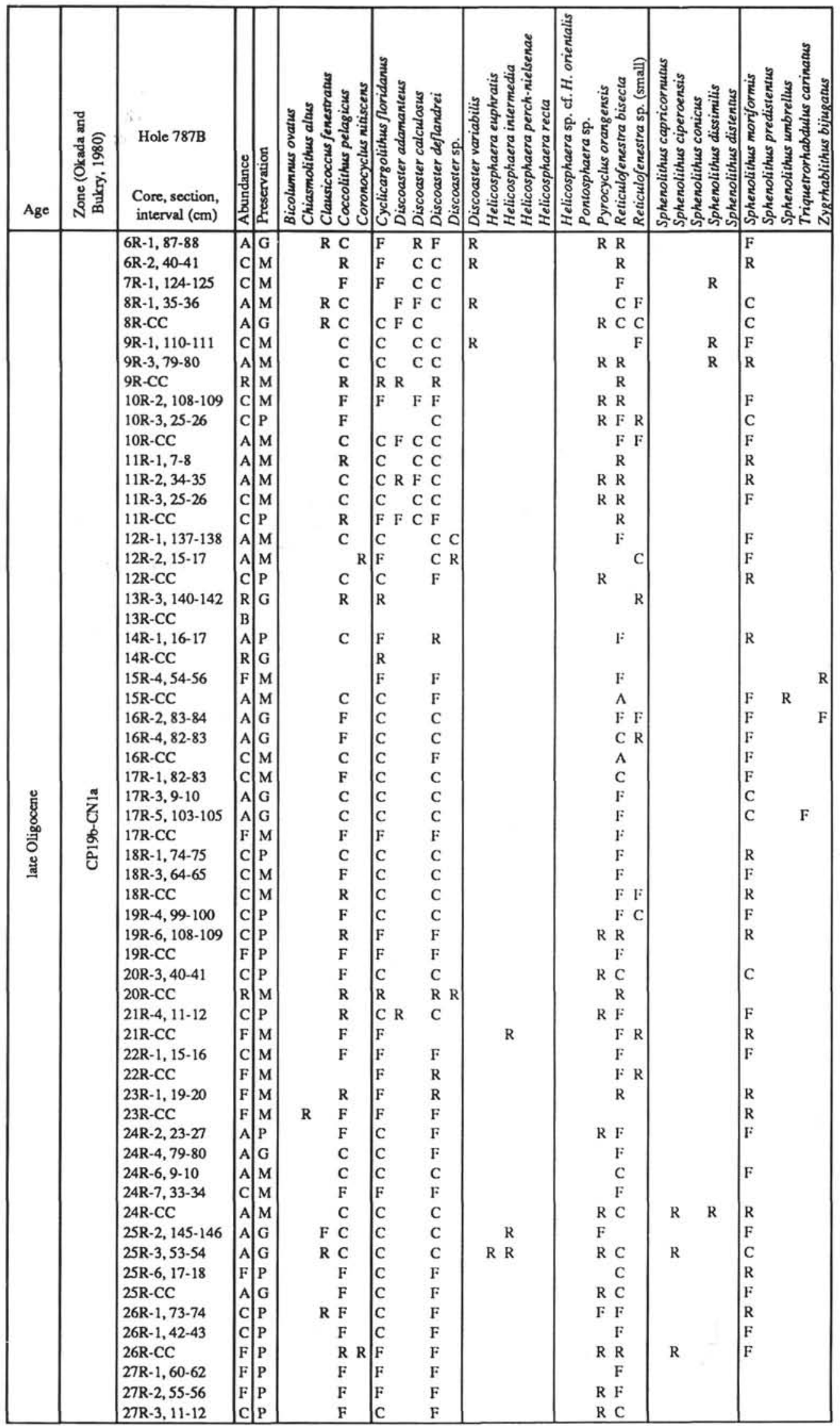


Table 5 (continued).

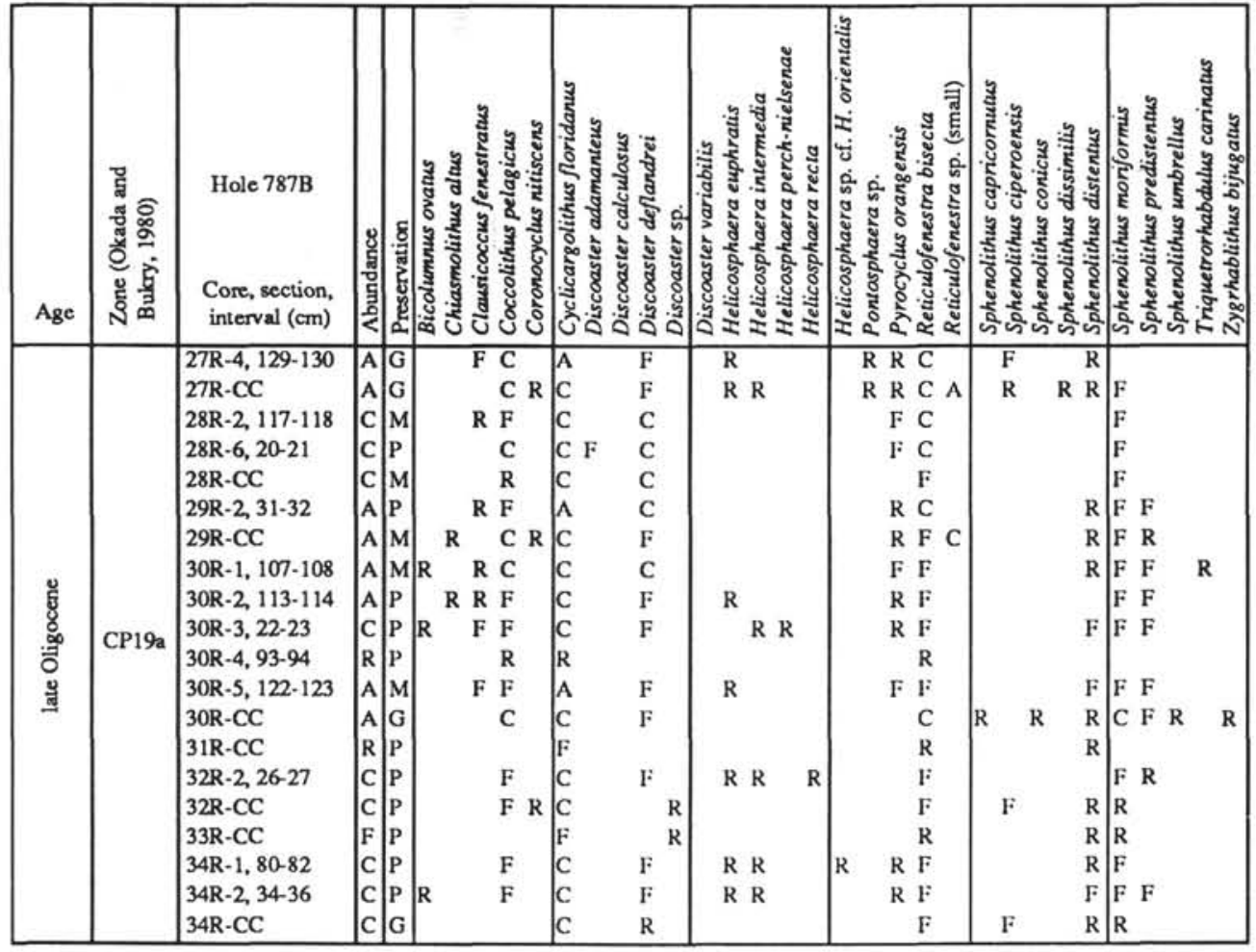

Note: Abundance: $A=$ abundant, $B=$ barren, $C=c o m m o n, F=f c w, R=r a r c$

Preservation: $\mathrm{G}=$ good, $\mathrm{M}=$ moderate, $\mathrm{P}=$-poor

in this section compared with D. hamatus. We choose not to subdivide Zone $\mathrm{CN} 7$ because of this uncertainty.

Zone CN8 ranges from Samples 126-792E-15R-1, $11-12 \mathrm{~cm}$, to -13R-CC, between the LO of D. hamatus and the FO of Discoaster berggrenii. The presence of Zone CN8 is questionable, however, because Discoaster quinqueramus has its FO in Sample 126-792E-15R-1, 11-12 $\mathrm{cm}$, below the FO of $D$. berggrenii. Discoaster quinqueramus usually has its FO at or above that of $D$. berggrenii (Perch-Nielsen, 1985). If we had used the nannofossil zonation of Martini (1971), there would be a missing zone (Zone NN10) between the LO of D. hamatus and the FO of $D$. quinqueramus. The radiolarian biostratigraphy at Site 792 (Taylor, Fujioka, et al., 1990) also indicates that there is a hiatus in this section between Samples 126-792E-15R-1, 11-12 cm, and -15R-2, 39-40 cm. Samples 126-792E-13R-1, 40-41 cm, through -6R-CC contain D. berggrenii and are assigned to Zone CN9. This zone could not be subdivided because of the absence of Amaurolithus primus in this section. Further discussion on some species within the middle to upper Miocene is found below.

\section{Chronostratigraphy}

The magnetostratigraphy of the sediments established on Leg 126 enables us to evaluate some of the nannofossil datums by means of interpolation between magnetic reversals. The depths and ages of the magnetic reversals are taken from Taylor, Fujioka, et al. (1990), except for the top of the first normal, Subchron C5A (Site 792). Taylor, Fujioka, et al. (1990; p. 258, fig. 36) interpreted this reversal to be the top of the second normal of Subchron C5A, with an age of $11.89 \mathrm{Ma}$. We think, however, that the long reversed interval above this datum best corresponds to Chron C5 (reversed), and that the two normal intervals between 335 and 350 mbsf best correspond to the first and second normals of Subchron C5A. Subchron C6C is recognized in the upper part of Hole 787B (Taylor, Fujioka, et al., 1990, fig. 27, pp. 84-86), above a reversed interval that in turn lies above multiple short reversals. This magnetostra- tigraphic assignment, however, should be considered very tentative because of low core recovery in this part of the section. Tables 8 and 11 list the magnetic reversal datums used for interpolation, and the calculated age values of some nannofossil datums from Sites 787, 792, and 793. Figure 8 shows the magnetostratigraphy and nannofossil datums with depth in core at Sites 787, 792, and 793.

The age estimate of the LO of $S$. distentus ranges from about 27.1 Ma at Site 792 to about 28.3 Ma at Site 787. Xu and Wise (in press) reported an age estimate of $28.5 \mathrm{Ma}$ for this event at nearby Site 782 . Wei and Wise (1989) stated that this datum is quite variable and thus unreliable because of the species' rare and sporadic occurrence in the upper part of its range. Sphenolithus distentus is rare and sporadic at the Leg 126 sites, and this most likely contributes to the variability of its LO in the Bonin forearc region.

The LO of S. ciperoensis has an age estimate of $28.1 \mathrm{Ma}$ at Site 787 and about 27.2 Ma at Site 793. At Site 792 its age estimate is about 27.3 $\mathrm{Ma}$, older than the $\mathrm{LO}$ of $S$. distentus. These age estimates are all considerably older than that reported by Berggren et al. (1985a; $25.2 \mathrm{Ma}$ ) or those summarized by Wei and Wise (1989) for several mid-latitude sites (centering on $25.9 \mathrm{Ma}$ ). The rare and sporadic occurrence of $S$. ciperoensis, and the variable preservation in the upper Oligocene sequences most likely contributes to the variability of this datum at the Leg 126 sites.

Within the Miocene of Site 792, the LO of $C$. floridanus was observed in the uppermost part of Subchron C5A, and by extrapolating $2 \mathrm{~m}$ below the base of the first normal in Chron C5 (Tables 8 and 11, Fig. 8), yielded an age estimate of about $11.7 \mathrm{Ma}$. This age estimate is comparable with the value of $11.6 \mathrm{Ma}$ by Berggren et al. (1985b), but it is significantly younger than the value of $12.5 \mathrm{Ma}$ calculated by Xu and Wise (in press) from nearby Site 782. At Site 292 in the Philippine Sea, the LO of $C$. floridanus occurs above the LO of $S$. heteromorphus and slightly below the FO of D. kugleri (Ellis, 1975). However, at Site 296, in the northern Philippine Sea at a similar latitude as the Leg 126 sites, $C$. floridanus has 
Table 6. Range chart of relative abundances of nannofossil species encountered in Oligocene sediments, Hole 792E.

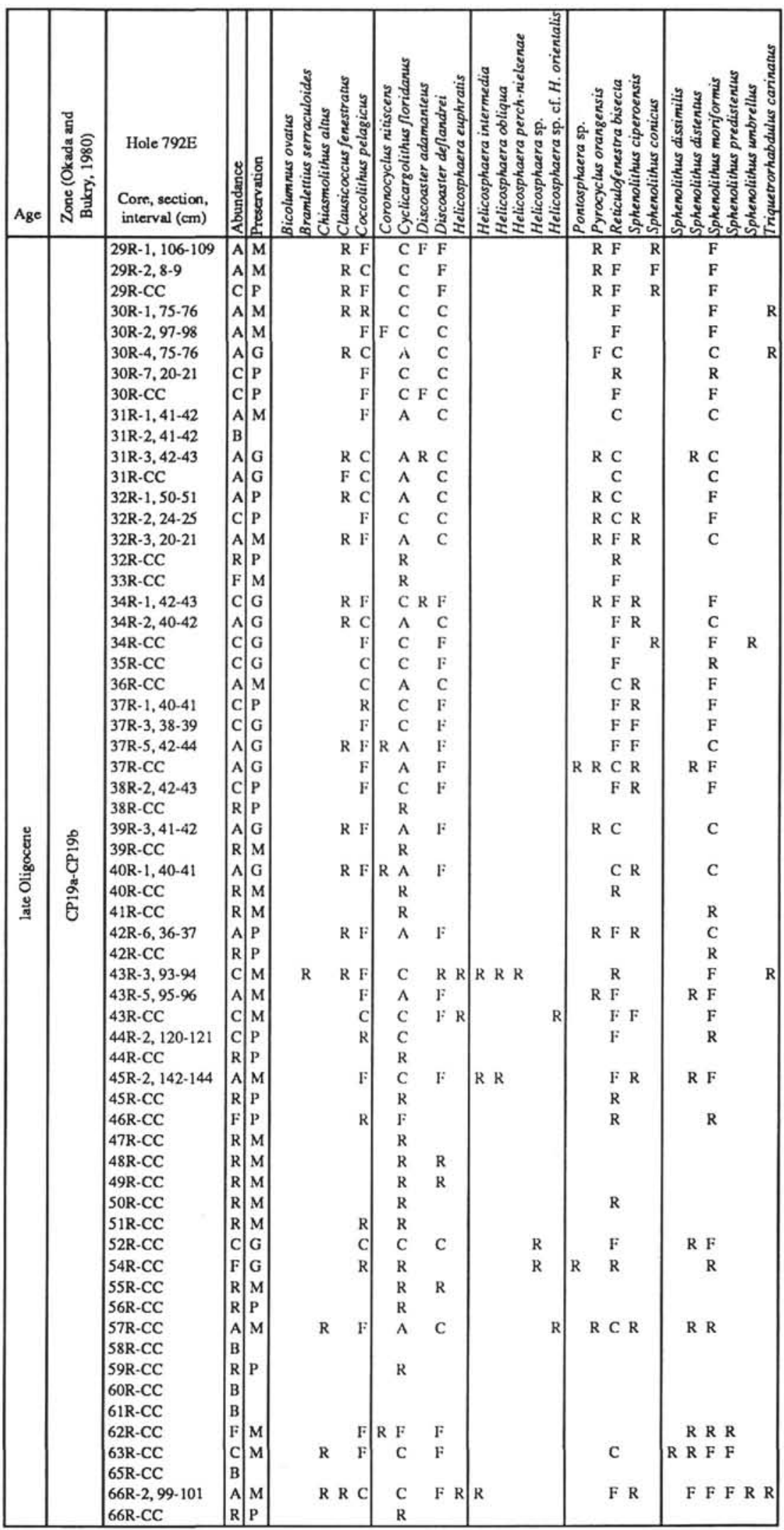

Note: Abundance: $A=a b u n d a n t, B=b a r r e n, ~ C=c o m m o n, F=f e w, R=r a r e$ Preservation: $\mathrm{G}=$ good, $\mathrm{M}=$ moderate, $\mathrm{P}=$ poor 
its LO below the LO of $S$. heteromorphus (Ellis, 1975). Rio et al. (1990) reported the LO of $C$. floridanus at the same level as the LO of $S$. heteromorphus (top of Zone CN4) and concluded that the LO of $C$. floridanus is diachronous over large geographic distances and must be used with caution.

Discoaster kugleri has a rare but consistent occurrence in the middle Miocene of Site 792. Its FO and LO are found by interpolation to have age estimates of about 11.2 and $10.7 \mathrm{Ma}$, respectively. In comparison, D. kugleri ranges from 12.5 to $10.5 \mathrm{Ma}$ at nearby Site 782 (Xu and Wise, in press). Rio et al. (1990) considered this species to be unreliable because of its rare and inconsistent occurrence.

The FO of $C$. coalitus has an age estimate of about $10.6 \mathrm{Ma}$, which is comparable with the values of $10.2 \mathrm{Ma}$ reported by $\mathrm{Xu}$ and Wise (in press) and $10.8 \mathrm{Ma}$ by Berggren et al. (1985b). The LO of $C$. coalitus has an age estimate of about $8.8 \mathrm{Ma}$, which compares closely with the $9.0 \mathrm{Ma}$ reported by $\mathrm{Xu}$ and Wise (in press).

The range of $C$. calyculus and $D$. hamatus are identical at Site 792, (i.e., about 9.6 to $8.8 \mathrm{Ma}$ ). At Site 782 , C. calyculus ranges from 9.8 to $9.0 \mathrm{Ma}$ (Xu and Wise, in press). Berggren et al. (1985b) report its FO at 10.0 Ma. Catinaster sp. cf. C. calyculus was differentiated from C. calyculus at Site 792 by having very small, straight rays projecting from the body, rather than having long, curved rays. This form occurred slightly older than $C$. calyculus sensu stricto, and may explain the older FO of C. calyculus reported at Site 782.

\section{SUMMARY}

During Leg 126, we recovered three expanded Pleistocene sections of less than 1.1 Ma and three expanded Oligocene-Miocene sections, all with good magnetostratigraphic control. Quantitative counts of Pleistocene nannofossils allowed the recognition of five assemblages between 0 and $1.0 \mathrm{Ma}$. Although based on broad species concepts within the genus Gephyrocapsa, these assemblages correspond closely to those assemblages recognized by Gartner (1977) and Matsuoka and Okada $(1989,1990)$ and further demonstrate the relative synchroneity of several assemblage changes in the middle to upper Pleistocene. A comparison of the assemblages between two adjacent $(2 \mathrm{~km})$ and geologically similar sites (Sites 790 and 791) show the lower limit of similarity based on quantitative analyses that may be expected between any two sites.

Site 787 may have a complete upper Oligocene section up to the Oligocene/Miocene boundary, based on magnetostratigraphy. Site 792 may be missing up to 3 m.y. of sediments from the uppermost Oligocene, whereas at Site 793 the last 3 m.y. of the Oligocene sediments are either missing or contained within a barren interval. Zone CN2 is missing from both Sites 792 and 793, and some of Zone CN3 and all of Zone CN4 are missing at Site 792. Nannofossil assemblages indicate a temperate paleoenvironment in the Oligocene and Miocene. Assessment of the biochronology of some nannofossil datums at the Leg 126 sites indicates that age estimates for $S$. distentus, $S$. ciperoensis, $C$. floridanus, and $D$. kugleri are significantly different from those reported from other regions, whereas the age estimates for $C$. coalitus and $C$. calyculus are roughly similar to those reported from other regions.

\section{ACKNOWLEDGMENTS}

Support for this study was funded by a research grant from USSAC, and by an equipment grant from the Amoco Foundation. We gratefully acknowledge the critical reviews by Gunnar Olafsson and Toshiaki Takayama.

\section{REFERENCES}

Backman, J., 1980. Miocene-Pliocene nannofossils and sedimentation rates in the Hatton-Rockall Basin, NE Atlantic Ocean. Stockholm Contrib. Geol., 36:1-91.
Berggren, W. A., Kent, D. V., and Flynn, J. J., 1985a. Jurassic to Paleogene: Part 2. Paleogene geochronology and chronostratigraphy. In Snelling, N. J. (Ed.), The Chronology of the Geological Record. Geol. Soc. London Mem., 10:141-195.

Berggren, W. A., Kent, D. V., and Van Couvering, J. A., 1985b. The Neogene: Part 2. Neogene geochronology and chronostratigraphy. In Snelling, N. J. (Ed.), The Chronology of the Geological Record. Geol. Soc. London Mem., 10:211-260.

Ellis, C. H., 1975. Calcareous nannofossil biostratigraphy-Leg 31, DSDP. In Karig, D. E., Ingle, J. C., Jr., et al., Init. Repts. DSDP, 31: Washington (U.S. Govt. Printing Office), 655-676.

Firth, J. V., in press. Analysis of the taxonomic, biostratigraphic and evolutionary relationships of species of the calcareous nannofossil genus Cyclicargolithus Bukry (1971) from the upper Eocene and Oligocene of the North Atlantic. Mem. Sci. Geol.

Fornaciari, E., Raffi, I., Rio, D., Villa, G., Backman, J., and Olafsson, G., 1990. Quantitative distribution patterns of Oligocene and Miocene calcareous nannofossils from the western equatorial Indian Ocean. In Backman, J., Duncan, R. A., Peterson, L. C., et al., Proc. ODP, Sci. Results, 115: College Station, TX (Ocean Drilling Program), 237-254.

Gartner, S., 1977. Calcareous nannofossil biostratigraphy and revised zonation of the Pleistocene. Mar. Micropaleontol., 2:1-25.

Geitzenauer, K. R., Roche, M. B., and McIntyre, A., 1977. Coccolith biogeography from North Atlantic and Pacific surface sediments. In Ramsay, A.T.S. (Ed.), Oceanic Micropaleontology: New York (Academic Press), 973-1008.

Honjo, S., 1977. Biogeography and provincialism of living coccolithophorids in the Pacific Ocean. In Ramsay, A.T.S. (Ed.), Oceanic Micropaleontology: New York (Academic Press), 951-972.

Honjo, S., and Okada, H., 1974. Community structure of coccolithophores in the photic layer of the mid-Pacific. Micropaleontology, 20:209-230.

Martini, E., 1971. Standard Tertiary and Quaternary calcareous nannoplankton zonation. In Farinacci, A. (Ed.), Proceedings of the Second International Conference on Planktonic Microfossils, Roma: Rome (Ed. Technoscienza), 739-785.

Matsuoka, H., and Okada, H., 1989. Quantitative analysis of Quaternary nannoplankton in the subtropical northwestern Pacific Ocean. Mar. Micropaleontol., 14:97-118.

, 1990. Time-progressive morphometric changes of the genus Gephyrocapsa in the Quaternary sequence of the tropical Indian Ocean. In Duncan, R. A., Backman, J., Peterson, L. C., et al., Proc. ODP, Sci. Results, 115: College Station, TX (Ocean Drilling Program), 255-270.

Okada, H., 1980. Calcareous nannofossils from Deep Sea Drilling Project Sites 442 through 446, Philippine Sea. In Klein, G. deV., Kobayashi, K., et al., Init. Repts. DSDP, 58: Washington (U.S. Govt. Printing Office), 549-565.

Okada, H., and Bukry, D., 1980. Supplementary modification and introduction of code numbers to the low-latitude coccolith biostratigraphic zonation (Bukry, 1973; 1975). Mar. Micropaleontol., 5:321-325.

Olafsson, G., in press. Oligocene/Miocene morphometric variability of the Cyclicargolithus group from the equatorial Atlantic and Indian Oceans. Mem. Sci. Geol.

Perch-Nielsen, K., 1985. Cenozoic calcareous nannofossils. In Bolli, H. M., Saunders, J. B., Perch-Nielsen, K. (Eds.), Plankton Stratigraphy: Cambridge (Cambridge Univ. Press), 427-554.

Rio, D., 1982. The fossil distribution of coccolithophore genus Gephyrocapsa Kamptner and related Plio-Pleistocene chronostratigraphic problems. In Prell, W. L., Gardner, J. V., et al., Init. Repts. DSDP, 68: Washington (U.S. Govt. Printing Office), 325-343.

Rio, D., Fornaciari, E., and Raffi, I., 1990. Late Oligocene through early Pleistocene calcareous nannofossils from westem equatorial Indian Ocean (Leg 115). In Duncan, R. A., Backman, J., Peterson, L. C., et al., Proc. ODP, Sci. Results, 115: College Station, TX (Ocean Drilling Program), 175-235.

Samtleben, C., 1980. Die Evolution der Coccolithophoriden-Gattung Gephyrocapsa nach Befunden im Atlantik. Paläontol. Z., 54:91-127.

Sato, T., and Takayama, T., in press. On the stratigraphically significant new species of calcareous nannofossil, Reticulofenestra asanoi. Professor Yokichi Takayanagi Memorial Volume.

Shipboard Scientific Party, 1990. Sites 790/791. In Taylor, B., Fujioka, K., et al., Proc. ODP, Init. Repts., 126: College Station, TX (Ocean Drilling Program), 127-220.

Takayama, T., and Sato, T., 1987. Coccolith biostratigraphy of the North Atlantic Ocean, Deep Sea Drilling Project Leg 94. In Ruddiman, W. F., Kidd, R. B., Thomas, E., et al., Init. Repts. DSDP, 94, Pt. 2: Washington (U.S. Govt. Printing Office), 651-702. 
Table 7. Range chart of relative abundances of nannofossil species encountered in Oligocene sediments, Hole 793B.

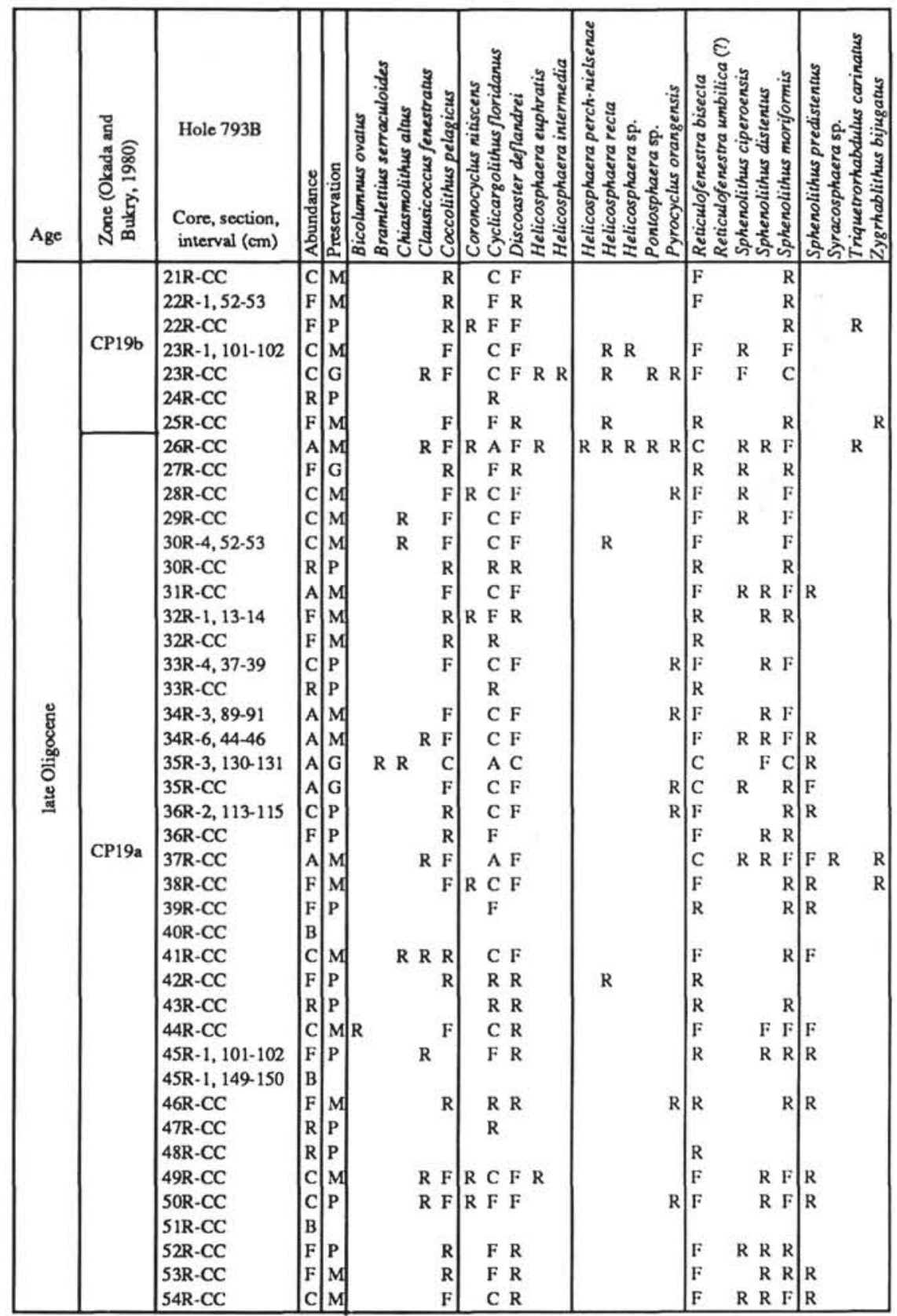

Note: Abundance: $\mathrm{A}=$ abundant, $\mathrm{B}=\mathrm{barren}, \mathrm{C}=\mathrm{common}, \mathrm{F}=\mathrm{few}, \mathrm{R}=$ rare Preservation: $\mathrm{G}=\mathrm{good}, \mathrm{M}=$ moderate, $\mathrm{P}=$ poor

Taylor, B., Fujioka, K., et al., 1990. Proc. ODP, Init. Repts., 126: College Station, TX (Ocean Drilling Program).

Thierstein, H. R., Geitzenauer, K. R., Molfino, B., and Shackleton, N. J., 1977. Global synchroneity of late Quaternary coccolith datum levels: validation by oxygen isotopes. Geology, 5:400-404.

van Andel, T. H., 1975. Mesozoic-Cenozoic calcite compensation depth and the global distribution of calcareous sediments. Earth Planet. Sci. Lett., 26:187-194.

Wei, W., and Wise, S. W., Jr., 1989. Paleogene calcareous nannofossil magnetobiochronology: results from South Atlantic DSDP Site 516. Mar. Micropaleontol., 14:119-152.
1990. Middle Eocene-Oligocene calcareous nannoplankton biogeographic gradient of the South Atlantic Ocean. Palaeogeogr., Palaeoclimatol., Palaeoecol., 79: 29-61.

$\mathrm{Xu}$, Y., and Wise, S. W., Jr., in press. Middle Eocene to Miocene calcareous nannofossils of ODP Leg 125 from the western Pacific Ocean. In Fryer, P., Pearce, J. A., Stokking, L. B., et al., Proc. ODP, Sci. Results, 125: College Station, TX (Ocean Drilling Program).

Date of initial receipt: 10 January 1991

Date of acceptance: 6 June 1991

Ms 126B-131 
Table 7 (continued).

\begin{tabular}{|c|c|c|c|c|c|c|c|c|c|c|}
\hline Age & 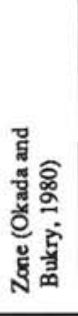 & $\begin{array}{l}\text { Hole 793B } \\
\text { Core, section, } \\
\text { interval (cm) }\end{array}$ & 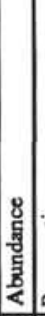 & : & 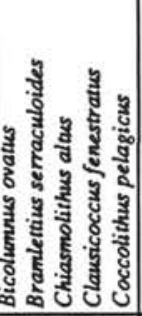 & 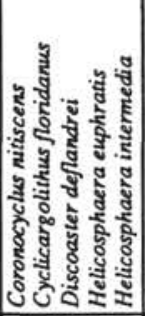 & 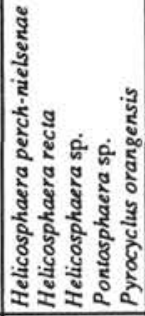 & 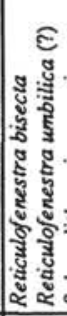 & 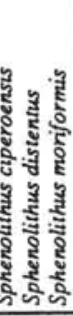 & 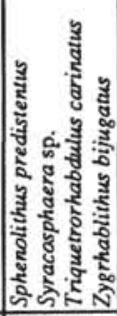 \\
\hline 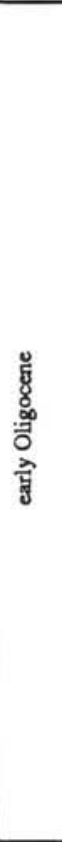 & 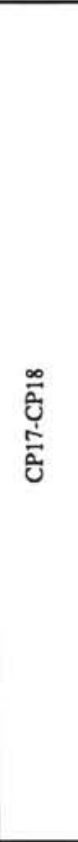 & \begin{tabular}{|l}
$55 R-C C$ \\
$56 R-C C$ \\
$57 R-3,82-83$ \\
$58 R-C C$ \\
$59 R-C C$ \\
$60 R-C C$ \\
$61 R-C C$ \\
$62 R-C C$ \\
$63 R-C C$ \\
$64 R-C C$ \\
$65 R-C C$ \\
$66 R-C C$ \\
$67 R-C C$ \\
$68 R-C C$ \\
$70 R-C C$ \\
$71 R-C C$ \\
$72 R-2,149-150$ \\
$73 R-C C$ \\
$74 R-1,23-24$ \\
$75 R-5,72-74$ \\
$75 R-C C$ \\
$76 R-7,39-40$ \\
$77 R-C C$ \\
$78 R-C C$ \\
$79 R-C C$ \\
$80 R-C C$ \\
$81 R-1,86-87$ \\
\end{tabular} & \begin{tabular}{|l|l|}
$B$ & $B$ \\
$C$ & \\
$R$ & $R$ \\
$R$ & \\
$R$ & $B$ \\
$B$ \\
$R$ \\
$B$ \\
$B$ \\
$R$ \\
$R$ \\
$C$ \\
$B$ \\
$F$ \\
$B$ \\
$R$ \\
$C$ \\
$R$ \\
$C$ \\
$R$ \\
$F$ \\
$F$ \\
$B$ \\
$F$
\end{tabular} & $\begin{array}{l}\mathrm{G} \\
\mathrm{P} \\
\mathrm{P} \\
\mathrm{P} \\
\mathrm{P} \\
\mathrm{M} \\
\\
\mathrm{P} \\
\mathrm{P} \\
\mathrm{M} \\
\mathrm{P} \\
\mathrm{P} \\
\mathrm{M} \\
\mathrm{M} \\
\mathrm{P} \\
\mathrm{M} \\
\mathrm{P} \\
\mathrm{M} \\
\mathrm{P}\end{array}$ & $\begin{array}{rr}\mathrm{F} \\
\mathrm{R} \\
\mathrm{R} & \mathrm{F} \\
& \\
\mathrm{R} \\
\mathrm{R}\end{array}$ & 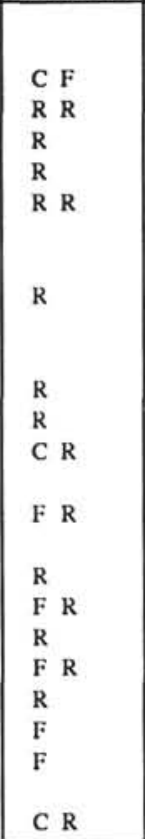 & & $\begin{array}{l}\mathrm{R} \\
\mathrm{I}: \\
\mathrm{F}: \\
\mathrm{R} \\
\mathrm{R} \\
\mathrm{F} \\
\mathrm{R} \\
\mathrm{F} \\
\mathrm{R} \\
\mathrm{R} \\
\mathrm{R} \\
\mathrm{R} \\
\mathrm{F}\end{array}$ & $\begin{array}{r}\mathrm{R} \\
\mathrm{F} \\
\mathrm{R} \\
\mathrm{F} \\
\mathrm{R} \\
\mathrm{R} \\
\mathrm{R} F\end{array}$ & $\int_{R}^{R}$ \\
\hline
\end{tabular}

Note: Abundance: $\mathrm{A}=\mathrm{abundant}, \mathrm{B}=\mathrm{barren}, \mathrm{C}=\mathrm{common}, \mathrm{F}=\mathrm{few}, \mathrm{R}=\mathrm{rare}$ Preservation: $\mathrm{G}=$ good, $M=$ moderate, $\mathrm{P}=$ poor

Table 8. Ages and depths of magnetic reversal datums, Sites 787, 792, and 793, used for age interpolation of nannofossil datums.

\begin{tabular}{|l|c|c|c|c|}
\hline \multicolumn{1}{|c|}{ Magnetic reversals } & \multicolumn{1}{|c|}{ Age } & \multicolumn{3}{|c|}{ Depth (mbsf) } \\
\hline \multicolumn{1}{|c|}{ Miocene } & (Ma) & Site 787 & Site 792 & Site 793 \\
\hline Top 1st normal, Chron C5 & 8.92 & - & $271.0-277.2$ & - \\
Base of 1st normal, Chron C5 & 10.42 & - & 302.0 & - \\
Top 1st normal, Chron C5A & 11.55 & - & $330.53-337.9$ & - \\
\hline \multicolumn{1}{|c|}{ Oligocene } & & Site 787 & Site 792 & Site 793 \\
\hline Base 3rd normal, Chron C6 & 24.21 & $51.1-58.8$ & - & - \\
Top 1st normal, Chron C8 & 26.86 & - & $418.45-419.86$ & 776.6 \\
Top 2nd normal, Chron C8 & 27.01 & $121.7-131.5$ & - & - \\
Base 2nd normal, Chron C8 & 27.74 & $170.8-171.04$ & - & $824.1-824.4$ \\
Top 1st normal, Chron C9 & 28.15 & $229.2-230.78$ & $466.2-475.9$ & $878.1-878.7$ \\
Base 1st normal, Chron C9 & 28.74 & $283.5-298.2$ & $621.96-628.43$ & - \\
Top 2nd normal, Chron C9 & 28.80 & - & $657.7-664.33$ & - \\
Base 2nd normal, Chron C9 & 29.21 & - & - & 967.9 \\
Top 1st normal, Chron C10 & 29.73 & - & - & $1091.73-1099.5$ \\
Top 2nd normal, Chron C10 & 30.09 & - & - & $1182.5-1187.0$ \\
Base 2nd normal, Chron C10 & 30.33 & - & - & 1255.5 \\
\hline
\end{tabular}


Table 9. Range chart of relative abundances of nannofossil species encountered in Miocene sediments, Hole 792E.

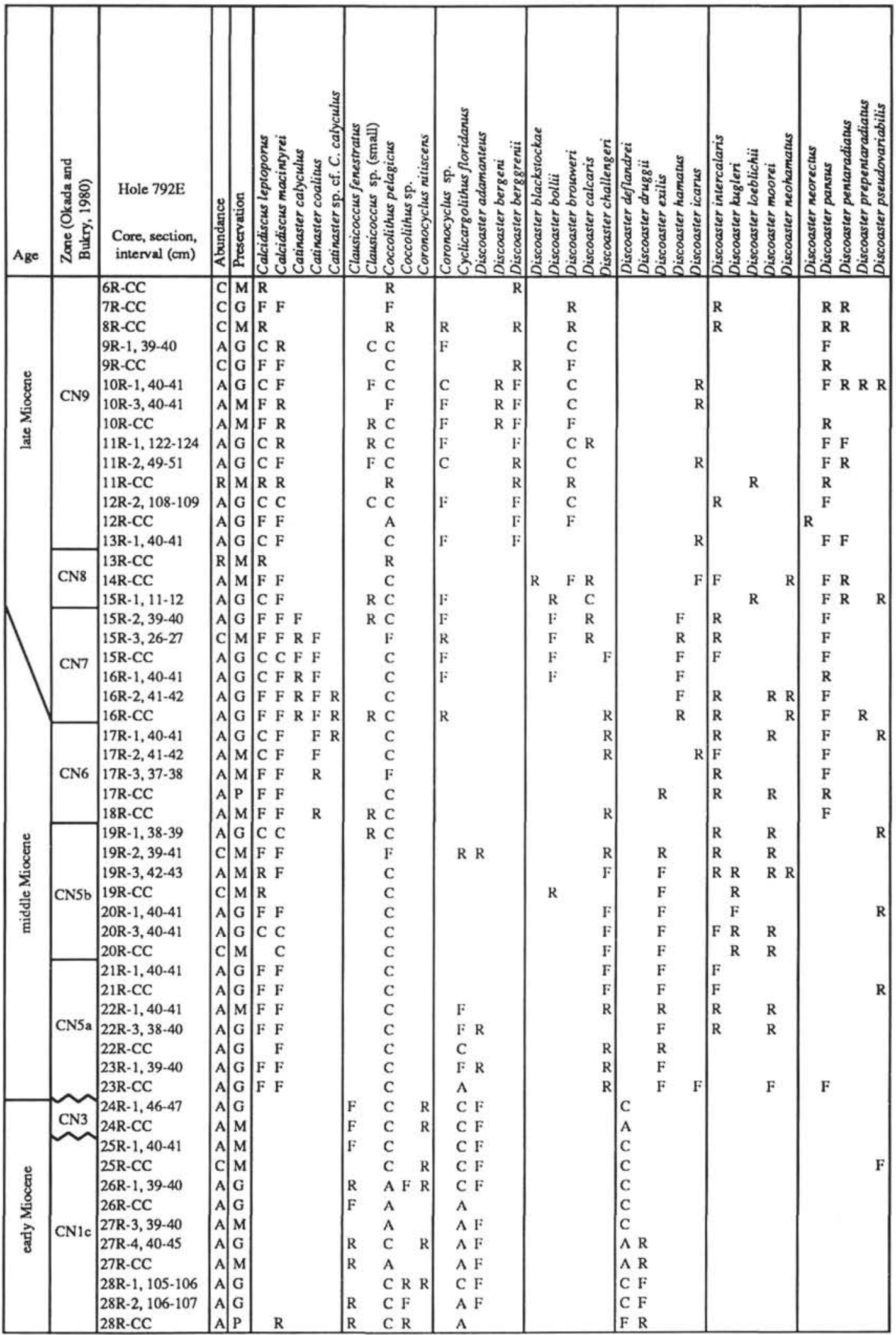

Note: Abundance: $\mathrm{A}=\mathrm{abundant}, \mathrm{C}=\mathrm{common}, \mathrm{F}=\mathrm{few}, \mathrm{R}=\mathrm{rare}$ Preservation: $\mathrm{G}=$ good, $\mathrm{M}=$ Moderate, $\mathrm{P}=$ poor 
Table 9 (continued)

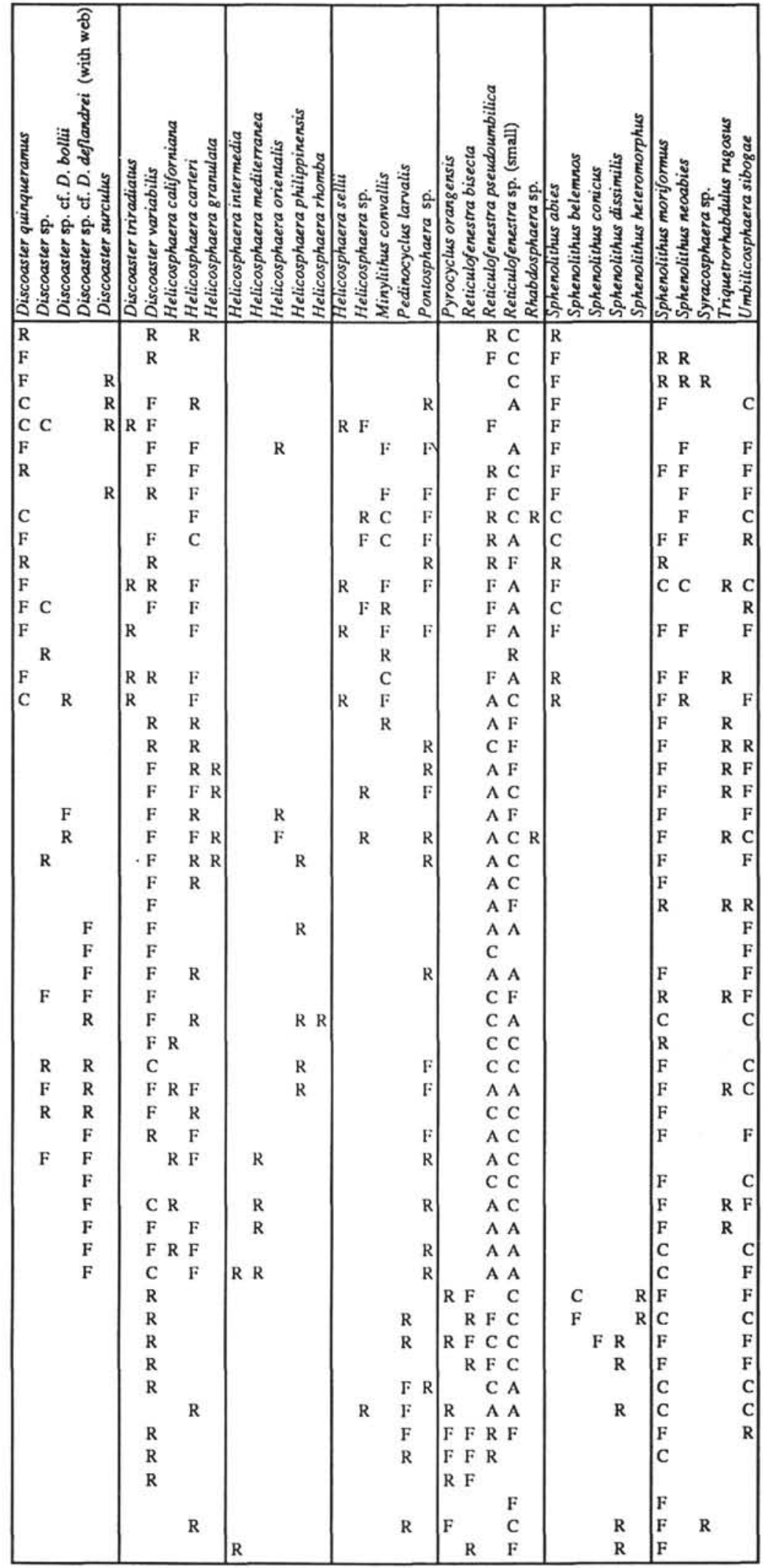


Table 10. Range chart of relative abundances of nannofossil species encountered in Miocene sediments, Hole 793B.

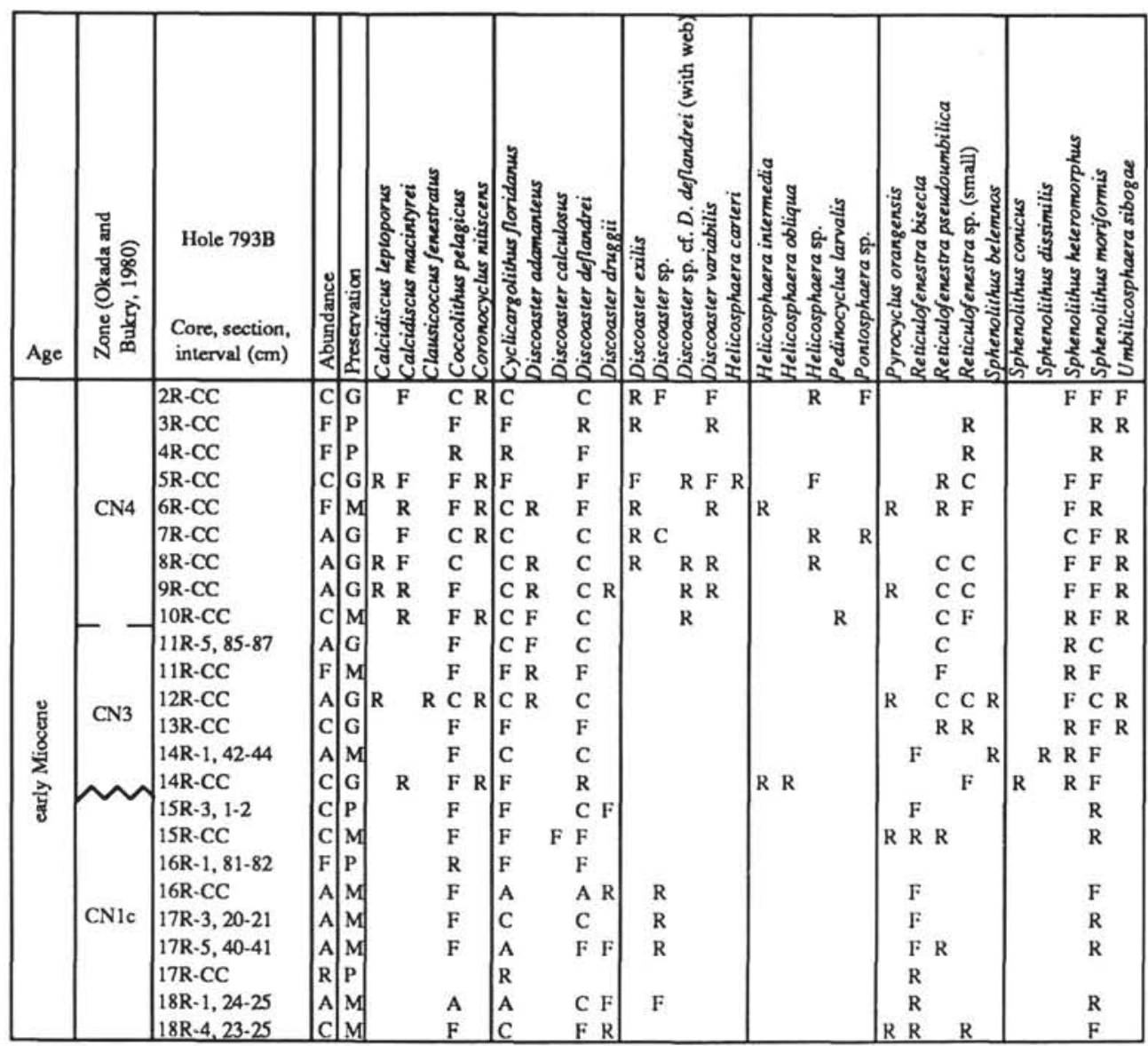

Note: Abundance: $\mathrm{A}=\mathrm{abundant}, \mathrm{C}=\mathrm{common}, \mathrm{F}=\mathrm{few}, \mathrm{R}=\mathrm{rare}$ Preservation: $\mathbf{G}=$ good, $\mathrm{M}=$ moderate, $\mathrm{P}=$ =poor

Table 11. Depth and interpolated age values of selected nannofossil species datums, Sites 787, 792, and 793.

\begin{tabular}{|l|c|c|c|c|c|c|}
\hline \multirow{2}{*}{\multicolumn{1}{|c|}{ Datum }} & \multicolumn{2}{c|}{ Site } & 787 & \multicolumn{2}{c|}{ Site 792 } & \multicolumn{2}{c|}{ Site 793 } \\
\cline { 2 - 7 } & Depth (mbsf) & Age (Ma) & Depth (mbsf) & Age (Ma) & Depth (mbsf) & Age (Ma) \\
\hline LO Catinaster calyculus & - & - & $270.6-272.4$ & $8.63-8.90$ & - & - \\
FO Catinaster calyculus & - & - & $282.9-290.3$ & $9.48-9.70$ & - & - \\
LO Discoaster hamatus & - & - & $270.6-272.4$ & $8.63-8.90$ & - & - \\
FO Discoaster hamatus & - & - & $282.9-290.3$ & $9.48-9.70$ & - & - \\
\hline LO Catinaster coalitus & - & - & $272.4-273.8$ & $8.72-8.99$ & - & - \\
FO Catinaster coalitus & - & - & $305.5-309.4$ & $10.54-10.63$ & - & - \\
LO Discoaster kugleri & - & - & $310.9-312.4$ & $10.72-10.74$ & - & - \\
FO Discoaster kugleri & - & - & $322.5-328.7$ & $11.19-11.22$ & - & - \\
\hline LO Cyclicargolithus floridanus & - & - & $338.3-341.3$ & $\mathrm{a}_{11.60-11.80}$ & - & - \\
LO Sphenolithus ciperoensis & $223.3-223.6$ & 28.10 & $435.1-436.3$ & $27.20-27.34$ & $791.9-798.0$ & $27.14-27.25$ \\
LO Sphenolithus distentus & $246.1-248.8$ & $28.31-28.33$ & $426.8-428.3$ & $27.02-27.12$ & $825.4-835.4$ & $27.75-27.83$ \\
FO Sphenolithus ciperoensis & - & - & - & - & $1101.6-1115.0$ & $29.77-29.79$ \\
\hline
\end{tabular}



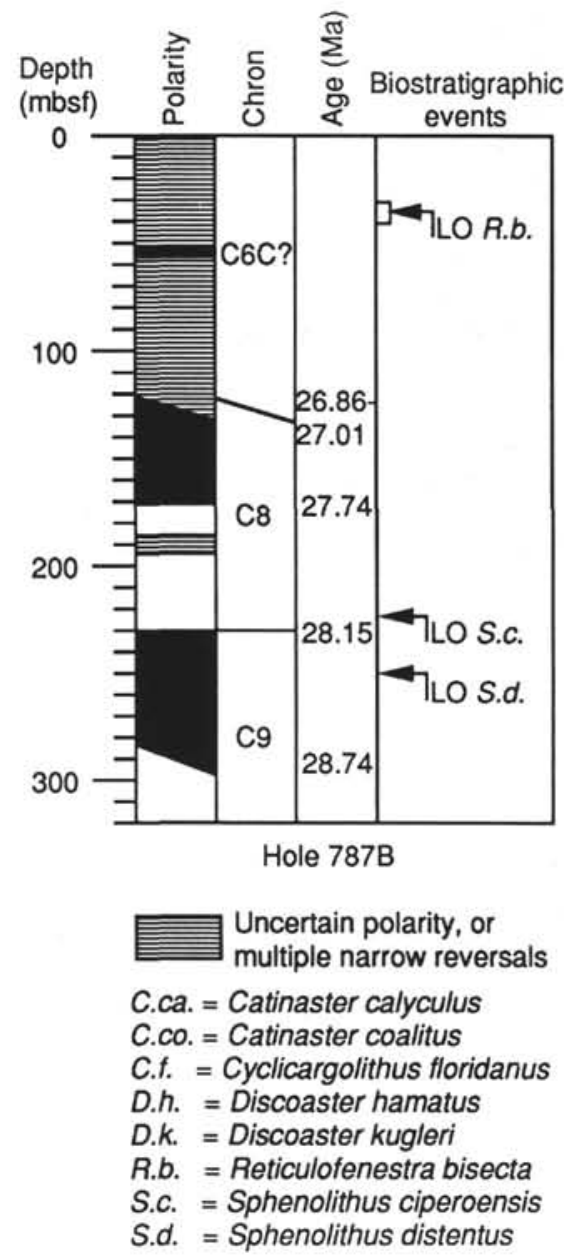
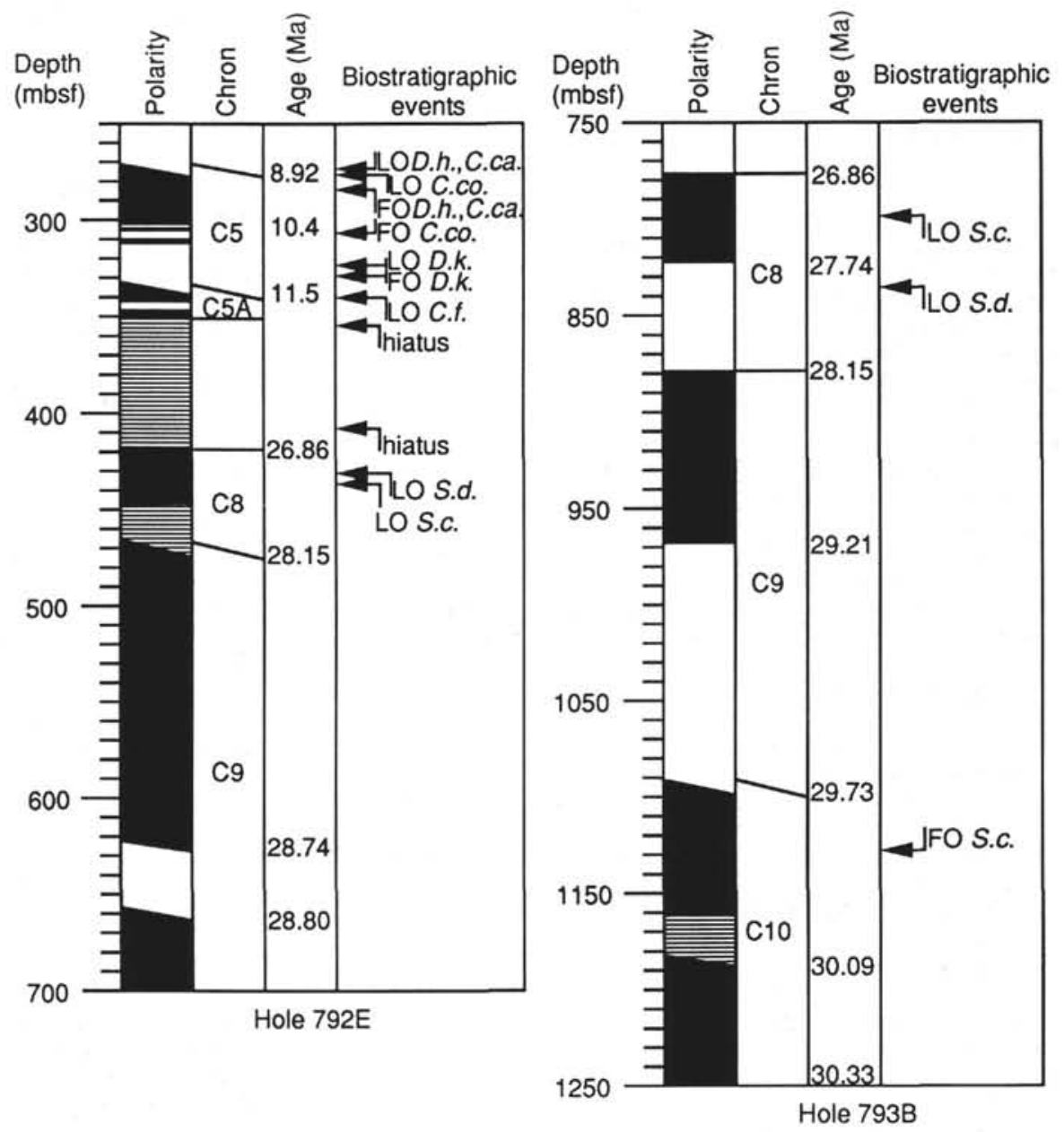

Figure 8. Magnetostratigraphy and biostratigraphic events in Holes 787B, 792E, and 793B. 


\section{APPENDIX}

\section{List of Species Considered in This Report}

Pleistocene species:

Calcidiscus leptoporus (Murray and Blackman, 1898) Loeblich and Tappan (1978)

Coccolithus pelagicus (Wallich, 1877) Schiller (1930)

Discolithina spp.

Emiliania huxleyi (Lohmann, 1902) Hay and Mohler in Hay et al. (1967)

Gephyrocapsa spp. (small)

Gephyrocapsa caribbeanica Boudreaux and Hay (1969)

Gephyrocapsa oceanica Kamptner (1943)

Helicosphaera inversa Gartner (1980)

Helicosphaera spp.

Pseudoemiliania lacunosa (Kamptner, 1963) Gartner (1969)

Reticulofenestra asanoi Sato and Takayama (in press)

Rhabdosphaera spp.

Syracosphaera pulchra Lohmann (1902)

Thoracosphaera spp.

Umbellosphaera irregularis Paasche in Markali and Paasche (1955)

Umbilicosphaera sibogae (Weber-van Bosse, 1901) Gaarder (1970)

\section{Oligocene and Miocene species:}

Bicolumnus ovatus Wei and Wise (1990)

Bramlettius serraculoides Gartner (1969)

Calcidiscus leptoporus (Murray and Blackman, 1898) Loeblich and Tappan (1978)

Calcidiscus macintyrei (Bukry and Bramlette, 1969) Loeblich and Tappan (1978)

Catinaster calyculus Martini and Bramlette (1963)

Catinaster coalitus Martini and Bramlette (1963)

Catinaster sp. cf. C. calyculus

Chiasmolithus altus Bukry and Percival (1971)

Clausicoccus fenestratus (Deflandre and Fert, 1954) Prins (1979)

Clausicoccus sp. (small)

Coccolithus pelagicus (Wallich, 1877) Schiller (1930)

Coccolithus sp.

Coronocyclus nitiscens (Kamptner, 1963) Bramlette and Wilcoxon (1967)

Coronocyclus sp.

Cyclicargolithus floridanus (Roth and Hay in Hay et al., 1967) Bukry (1971)

Discoaster adamanteus Bramlette and Wilcoxon (1967)

Discoaster bergeni Knüttel et al. (1989)

Discoaster berggrenii Bukry (1971)

Discoaster blackstockae Bukry (1973)

Discoaster bollii Martini and Bramlette (1963)

Discoaster sp. cf. D. bollii

Discoaster brouweri Tan (1927) emend. Bramlette and Riedel (1954)

Discoaster calcaris Gartner (1967)

Discoaster calculosus Bukry (1971)

Discoaster challengeri Bramlette and Riedel (1954)

Discoaster deflandrei Bramlette and Riedel (1954)

Discoaster sp. cf. D. deflandrei

Discoaster druggii Bramlette and Wilcoxon (1967)

Discoaster exilis Martini and Bramlette (1963)

Discoaster hamatus Martini and Bramlette (1963)
Discoaster icarus Stradner (1973)

Discoaster intercalaris Bukry (1971)

Discoaster kugleri Martini and Bramlette (1963)

Discoaster loeblichii Bukry (1971)

Discoaster moorei Bukry (1971)

Discoaster neohamatus Bukry and Bramlette (1969)

Discoaster neorectus Bukry (1971)

Discoaster pansus Bukry and Percival (1971) Bukry (1973)

Discoaster pentaradiatus Tan (1927) emend, Bramlette and Riedel (1954)

Discoaster prepentaradiatus Bukry and Percival (1971)

Discoaster pseudovariabilis Martini and Worsley (1971)

Discoaster quinqueramus Gartner (1969)

Discoaster sp.

Discoaster surculus Martini and Bramlette (1963)

Discoaster triradiatus Tan (1927)

Discoaster variabilis Martini and Bramlette (1963)

Helicosphaera californiana Bukry (1981)

Helicosphaera carteri (Wallich, 1877) Kamptner (1954)

Helicosphaera euphratis Haq (1966)

Helicosphaera granulata Bukry and Percival (1971)

Helicosphaera intermedia Martini (1965)

Helicosphaera mediterranea Müller (1981)

Helicosphaera obliqua Bramlette and Wilcoxon (1967)

Helicosphaera orientalis Black (1971)

Helicosphaera sp. cf. H. orientalis

Helicosphaera perch-nielsenae Haq (1971)

Helicosphaera philippinensis Müller (1981)

Helicosphaera recta Haq (1966)

Helicosphaera rhomba Bukry (1971)

Helicosphaera sellii Bukry and Bramlette (1969)

Helicosphaera sp.

Minylithus convallis Bukry (1973)

Pedinocyclus larvalis (Bukry and Bramlette, 1969) Loeblich and Tappan (1973)

Pontosphaera spp.

Pyrocyclus orangensis Hay and Towe (1962)

Reticulofenestra bisecta (Hay, Mohler, and Wade, 1966) Roth (1970)

Reticulofenestra pseudoumbilica (Gartner, 1967) Gartner (1969)

Reticulofenestra spp. (small)

Reticulofenestra umbilica (Levin, 1965) Martini and Ritzkowski (1968)

Rhabdosphaera spp.

Sphenolithus abies Deflandre in Deflandre and Fert (1954)

Sphenolithus belemnos Bramlette and Wilcoxon (1967)

Sphenolithus capricornutus Bukry and Percival (1971)

Sphenolithus ciperoensis Bramlette and Wilcoxon (1967)

Sphenolithus conicus Bukry (1971)

Sphenolithus dissimilis Bukry and Percival (1971)

Sphenolithus distentus (Martini, 1965) Bramlette and Wilcoxon (1967)

Sphenolithus heteromorphus Deflandre (1953)

Sphenolithus moriformis (Brönnimann and Stradner, 1960) Bramlette and Wilcoxon (1967)

Sphenolithus neoabies Bukry and Bramlette (1969)

Sphenolithus predistentus Bramlette and Wilcoxon (1967)

Sphenolithus umbrellus (Bukry, 1971) Aubry and Knüttel in Knüttel (1986)

Syracosphaera spp.

Triquetrorhabdulus carinatus Martini (1965)

Triquetrorhabdulus rugosus Bramlette and Wilcoxon (1967)

Umbilicosphaera sibogae (Weber-van Bosse, 1901) Gaarder (1970)

Zygrhablithus bijugatus Deflandre in Deflandre and Fert (1954) Deflandre (1959) 


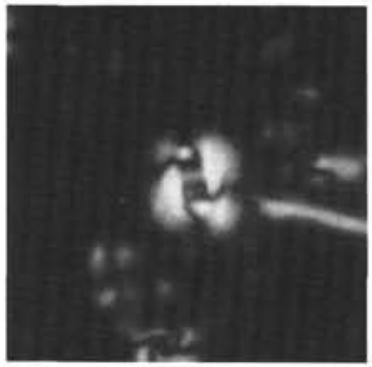

1

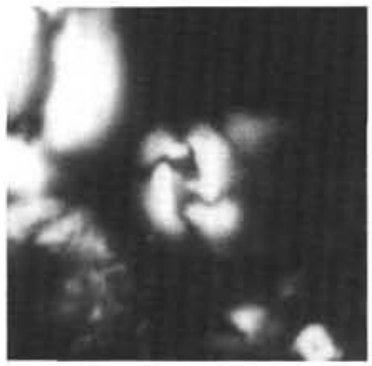

5

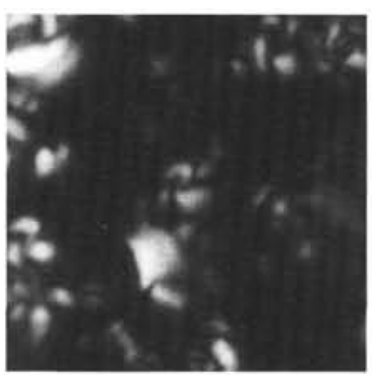

9

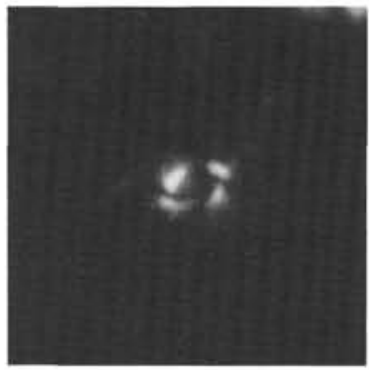

13

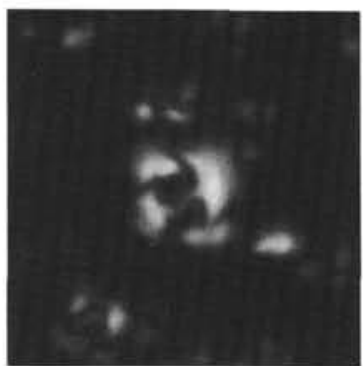

2

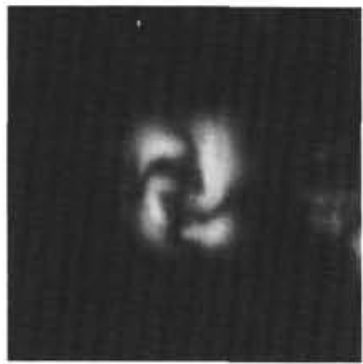

6

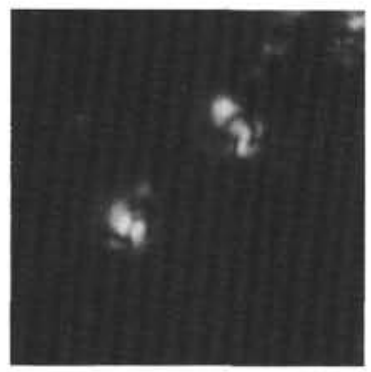

10

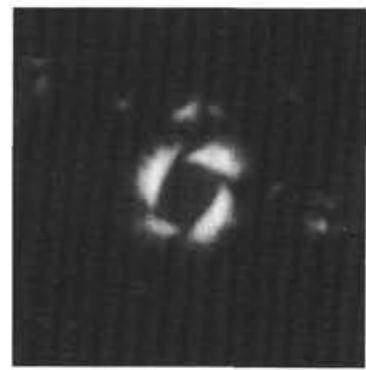

14

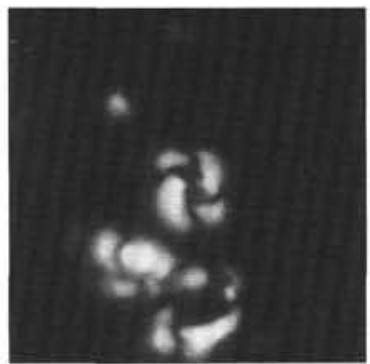

3

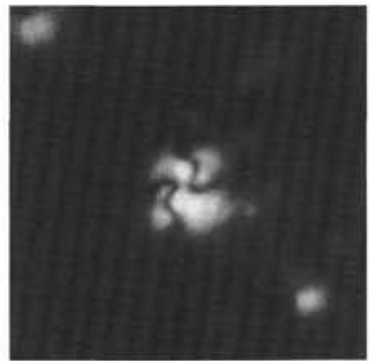

7

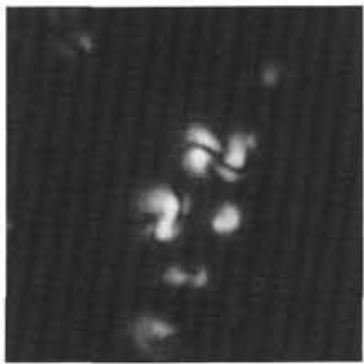

11

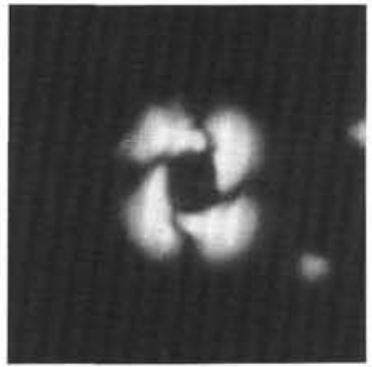

15

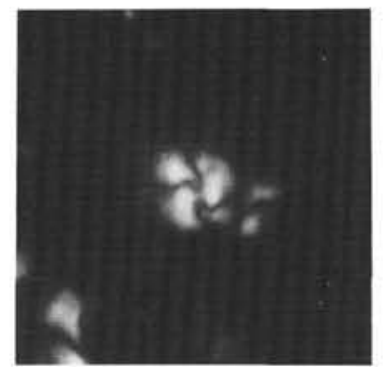

4

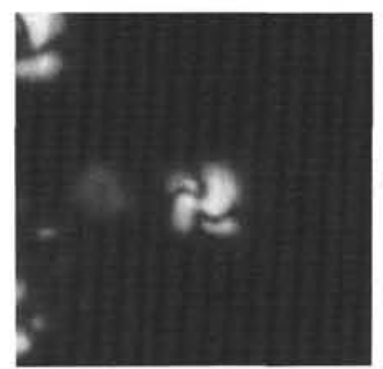

8

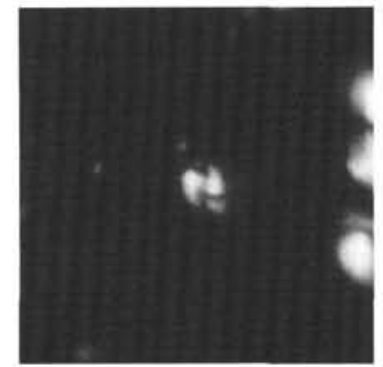

12

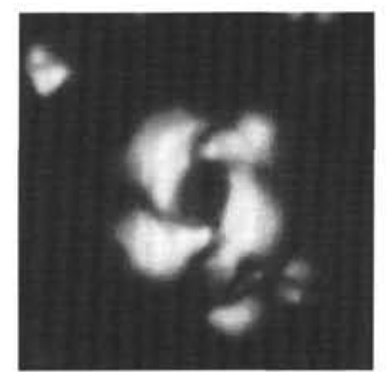

16

Plate 1. Pleistocene nannofossils. 1, 2. Gephyrocapsa oceanica with low bridge angle, Sample 126-790C-18X-1, 40-41 cm. 3,4. Gephyrocapsa caribbeanica, with low bridge angle, Sample 126-790C-19X-3, $40-41 \mathrm{~cm}$. 5, 6. Gephyrocapsa oceanica with high bridge angle, Sample 126-790C-6H-3, $0 \mathrm{~cm} . \quad 7,8$. Gephyrocapsa caribbeanica with high bridge angle, Sample 126-790C-13X-1, $60 \mathrm{~cm}$. 9. Gephyrocapsa sp. (small), Sample 126-790C-18X-1, 40-41 cm. 10, 11, 12. Gephyrocapsa spp. (small), Sample 126-790C-18X-5, 21-22 cm. 13. Emiliania huxleyi, Sample 126-790B-6H-3, 97-98 cm. 14. Pseudoemiliania lacunosa, Sample 126-790C-18X-5, 21-22 cm. 15, 16. Reticulofenestra asanoi, Sample 126-790C-19X-3, 40-41 cm. All photographs 3430X 


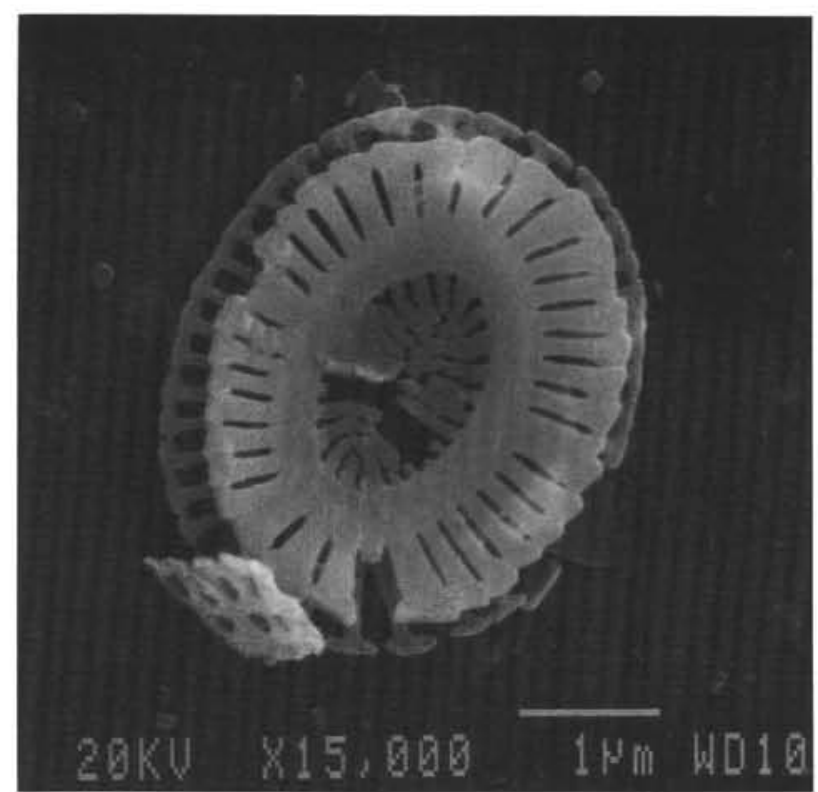

1

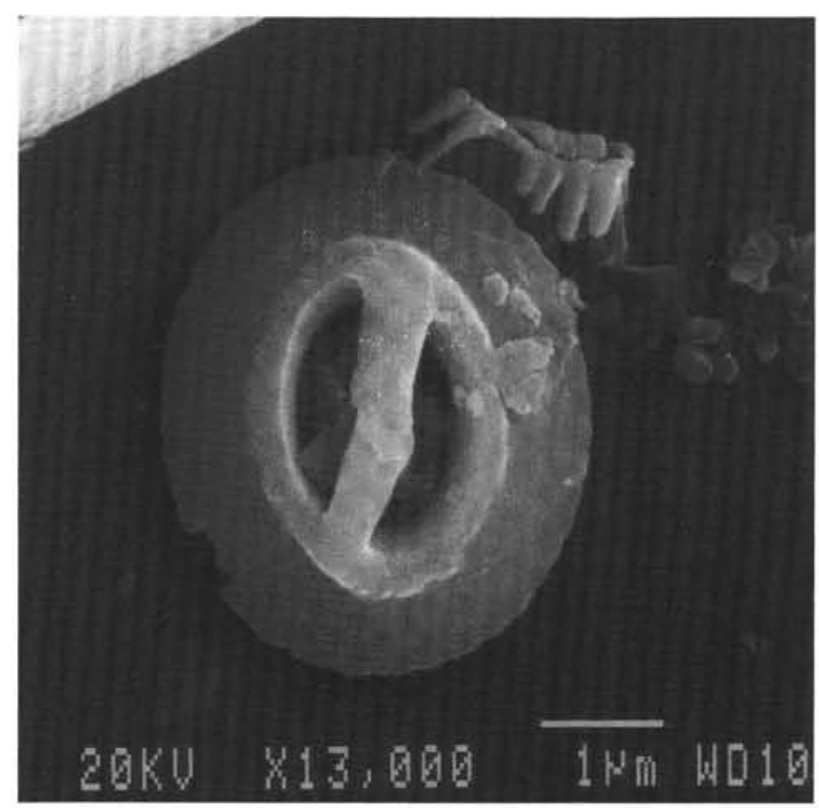

3

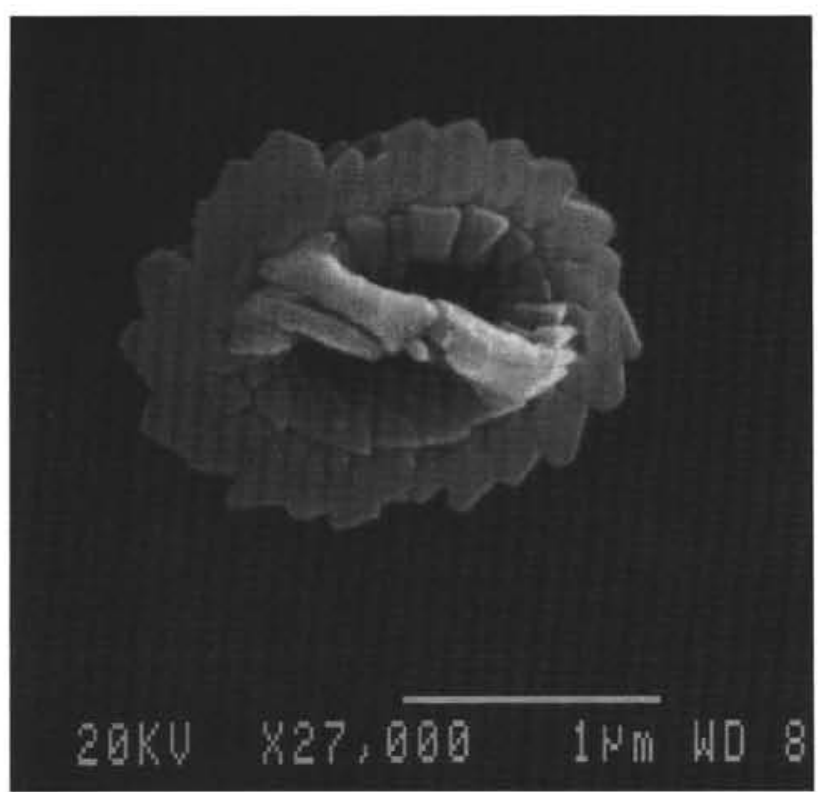

2

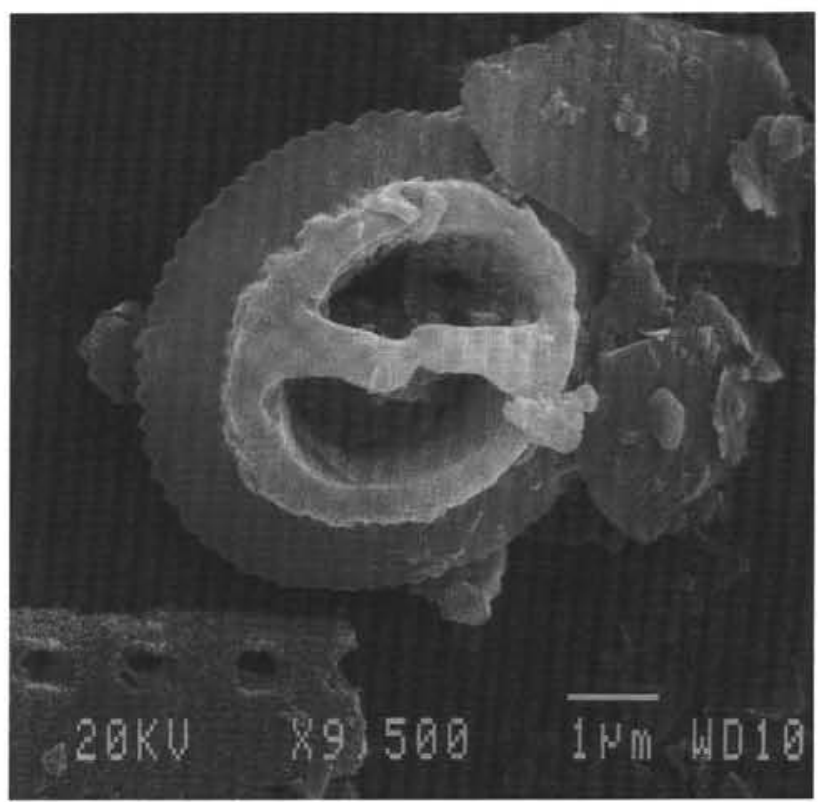

4

Plate 2. SEM photomicrographs of Pleistocene nannofossils. 1. Emiliania huxleyi, Sample 126-790A-2H-5, 125-126 cm. 2. Gephyrocapsa sp. (small), Sample 126-792A-2H-3, 147-148 cm. 3. Gephyrocapsa caribbeanica, with high bridge angle, Sample 126-790A-2H-5, 125-126 cm. 4. Gephyrocapsa oceanica with high bridge angle, Sample 126-790A-2H-5, 125-126 cm. Scale bars are $1 \mu \mathrm{m}$. 


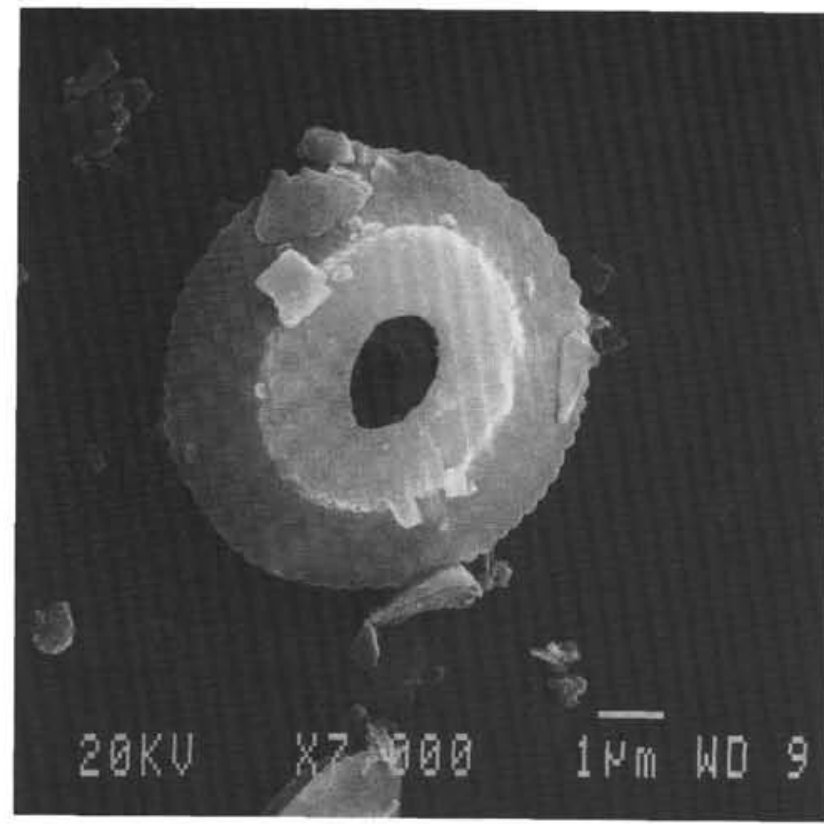

1

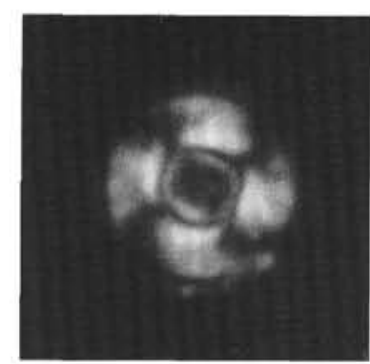

2

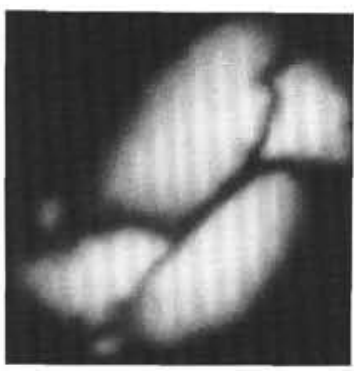

4

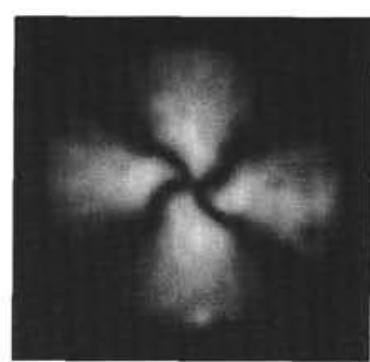

3

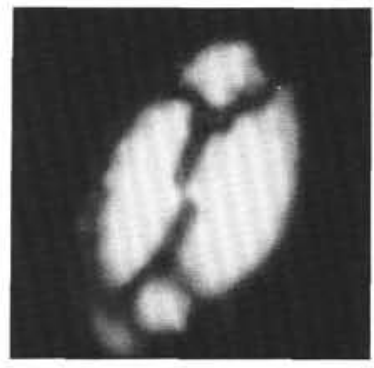

5

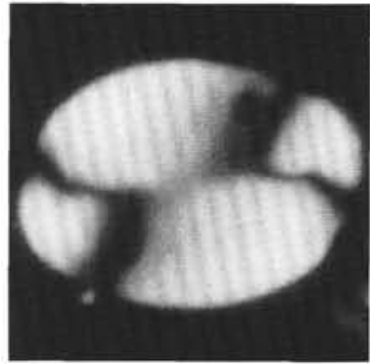

7

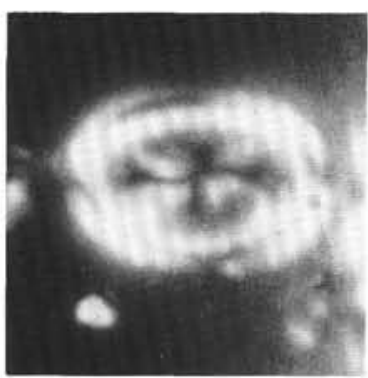

8

6

Plate 3. SEM and light photomicrographs of Pleistocene nannofossils. 1. Reticulofenestra asanoi, Sample 126-792B-5X-CC. 2. Umbilicosphaera sibogae, Sample 126-790B-15X-1, 22-24 cm, 6153X 3. Calcidiscus leptoporus, Sample 126-790B-15X-1, 22-24 cm, $4142 \times \quad 4$. Helicosphaera carteri, Sample 126-792A-2H-3, 147-148 cm, 5066× 5. Helicosphaera wallichii, Sample 126-792B-1H-1,5-6 cm, 4666× 6. Umbellosphaera irregularis (on left) and Pontosphaera sp. (on right), Sample 126-790A-2H-5, 125-126 cm. 7. Pontosphaera sp., Sample 126-792E-3R-1, 38-39 cm, 4375× 8. Syracosphaera pulchra, Sample 126-792E-3R-1, 38-39 cm, 4869× Scale bars on SEM photos are $1 \mu \mathrm{m}$. 

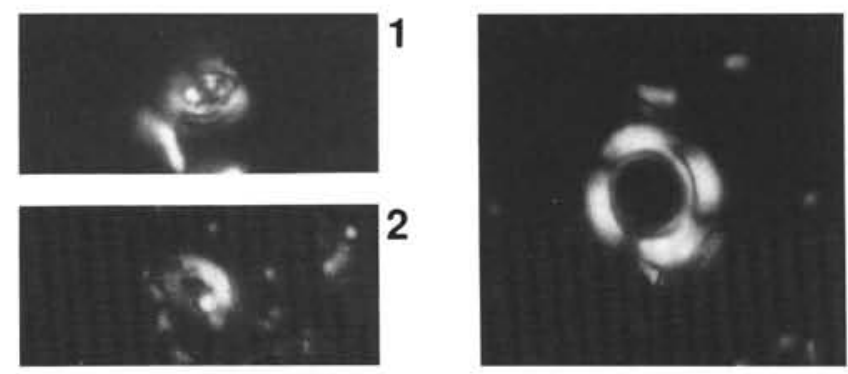

3

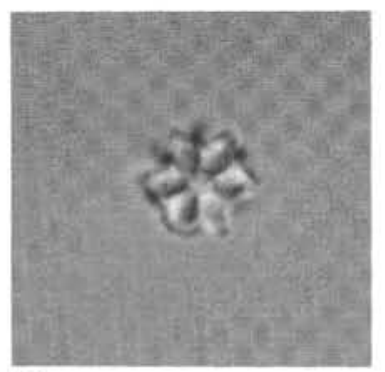

6

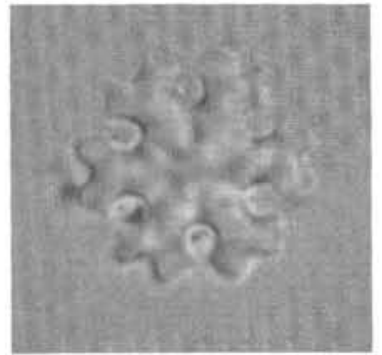

10

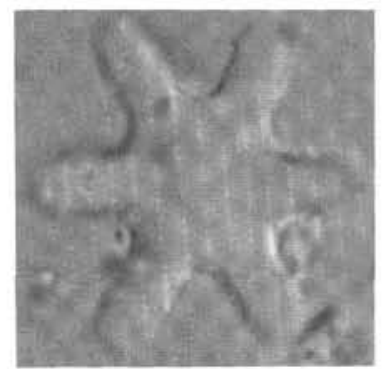

14

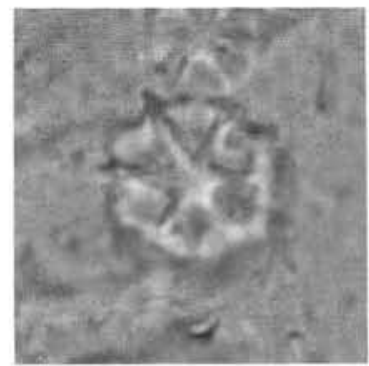

7

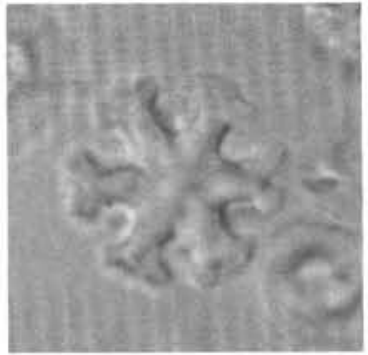

11

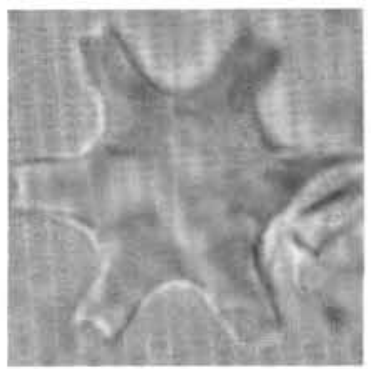

15

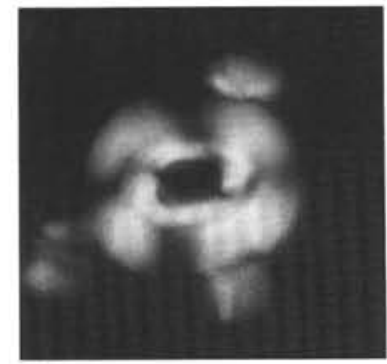

4

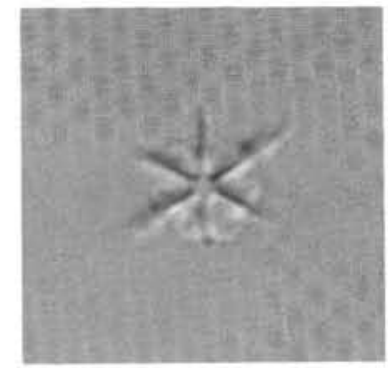

8

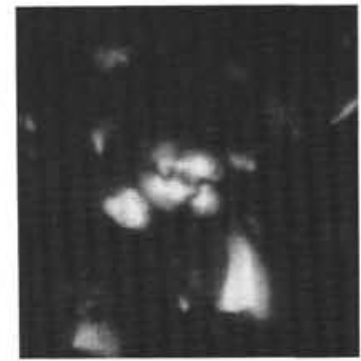

5

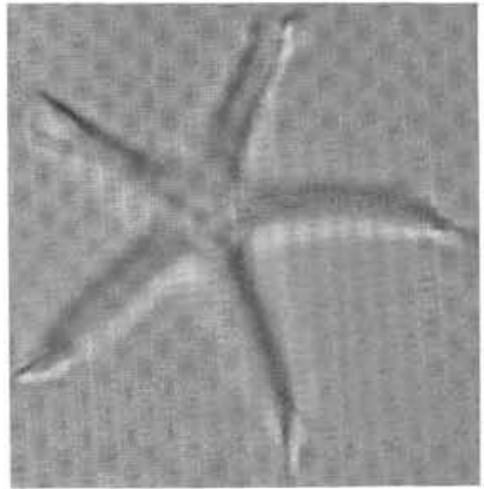

9

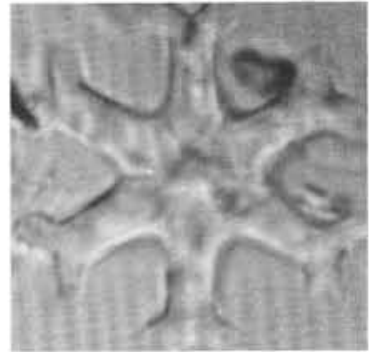

12

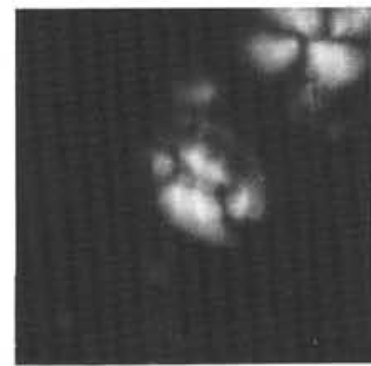

16

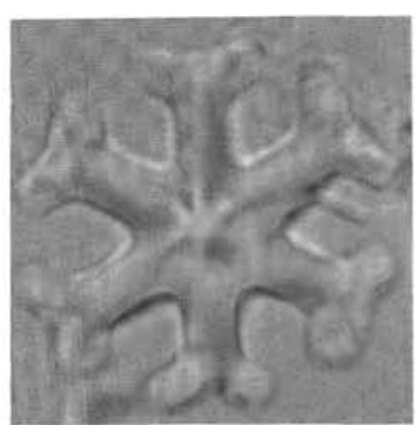

13

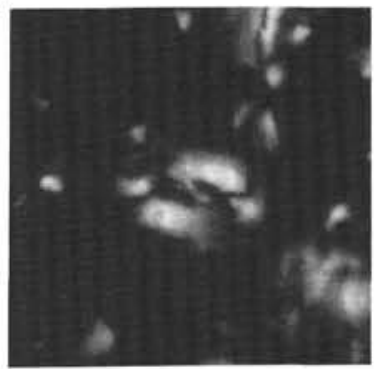

17

Plate 4. Miocene nannofossils. 1. Clausicoccus sp. (small), Sample 126-792E-16R-CC. 2. Clausicoccus sp. (small), Sample 126-792E-12R-2, 108-109 cm. 3. Coronocyclus sp., Sample 126-792E-11R-2, 49-51 cm. 4. Reticulofenestra pseudoumbilica, Sample 126-792E-16R-CC. 5. Reticulofenestra sp. (small), Sample 126-792E-11R-2, 49-51 cm. 6. Catinaster coalitus, Sample 126-792E-16R-CC. 7. Catinaster sp. cf. C. calyculus, Sample 126-792E-17R-1, 40-41 cm. 8. Catinaster calyculus, Sample 126-792E-16R-CC. 9. Discoaster hamatus, Sample 126-792E-16R-2, 41-42 cm. 10. Discoaster deflandrei, Sample 126-792E$28 \mathrm{R}-1,105-106 \mathrm{~cm}$. 11. Discoaster sp. cf. D. deflandrei (with web), Sample 126-792E-22R-3, 38-40 cm, shows web-like structure between bifurcations. 12. Discoaster variabilis, Sample 126-792E-11R-2, 49-51 cm. 13. Discoaster pansus, Sample 126-792E-16R-2, 41-42 cm. 14. Discoaster druggii, Sample 126-792E-28R-1, 105-106 cm. 15. Discoaster kugleri, Sample 126-792E-19R-3, 42-43 cm. 16. Helicosphaera sp., Sample 126-792E-16R-CC. 17. Helicosphaera sp., Sample 126-792E-11R-2, 49-51 cm. All photographs 2400X 